\title{
Role of anabolic agents in colorectal carcinogenesis: Myths and realities (Review)
}

\author{
THEODORE KRASANAKIS ${ }^{1 *}$, TAXIARCHIS KONSTANTINOS NIKOLOUZAKIS ${ }^{1 *}$, \\ MARKOS SGANTZOS ${ }^{2}$, THEODORE MARIOLIS-SAPSAKOS ${ }^{3}$, JOHN SOUGLAKOS ${ }^{4}$, \\ DEMETRIOS A. SPANDIDOS ${ }^{5}$, CHRISTINA TSITSIMPIKOU ${ }^{6}$, ARISTIDIS TSATSAKIS ${ }^{7}$ and JOHN TSIAOUSSIS $^{1}$ \\ ${ }^{1}$ Laboratory of Anatomy-Histology-Embryology, Medical School, University of Crete, 71110 Heraklion; \\ ${ }^{2}$ Faculty of Medicine, Department of Anatomy, Faculty of Medicine, University of Thessaly, 41221 Larissa; \\ ${ }^{3}$ National and Kapodistrian University of Athens, Agioi Anargyroi General and Oncologic Hospital of Kifisia, \\ 14564 Athens; ${ }^{4}$ Department of Medical Oncology, University General Hospital of Heraklion, 71110 Heraklion; \\ ${ }^{5}$ Laboratory of Clinical Virology, Medical School, University of Crete, 71409 Heraklion; \\ ${ }^{6}$ General Chemical State Laboratory of Greece, 11521 Athens; ${ }^{7}$ Department of Forensic Sciences \\ and Toxicology, Medical School, University of Crete, 71409 Heraklion, Greece
}

Received August 27, 2019; Accepted October 1, 2019

DOI: $10.3892 / o r .2019 .7351$

\begin{abstract}
Colorectal cancer (CRC) is one of the four leading causes of cancer-related mortality worldwide. Even though over the past few decades the global scientific community has made tremendous efforts to understand this entity, many ques-
\end{abstract}

Correspondence to: Dr John Tsiaoussis, Laboratory of Anatomy-Histology-Embryology, Medical School, University of Crete, Voutes, 71110 Heraklion, Greece

E-mail: tsiaoussis@uoc.gr

Professor Aristidis Tsatsakis, Department of Forensic Sciences and Toxicology, Medical School, University of Crete, Voutes, 71409 Heraklion, Greece

E-mail: tsatsaka@uoc.gr

${ }^{*}$ Co-first authorship

Abbreviations: CRC, colorectal cancer; DHT, dihydrotestosterone; IGF, insulin-like growth factor; FAP, familial adenomatous polyposis; HNPCC, hereditary non-polyposis colorectal cancer; CAC, colitis-associated cancer; TAMs, tumor-associated macrophages; STAT3, signal transducer and activator of transcription 3; IECs, intestinal epithelial cells; GH, growth hormone; DHEAS, dehydroepiandrosterone sulfate; DHEA, dehydroepiandrosterone; $\mathrm{GnRH}$, gonadotropin-releasing hormone; ARs, androgen receptors; AAS, anabolic-androgenic steroids; SARMs, selective androgen receptor modulators; IR, insulin receptor; EIR, epithelial insulin receptor; VIR, vascular insulin receptor; IGF-R, insulin-like growth factor receptor; IGFBPs, insulin-like growth factor binding proteins; VDR, vitamin D receptor; VEGF, vascular endothelial growth factor; EGF, epidermal growth factor; RXR, retinoid $\mathrm{X}$ receptor; VDREs, vitamin D response elements

Key words: anabolic agents, androgens, colorectal cancer, testosterone, dehydroepiandrosterone, vitamin D, insulin, IGF-1, growth hormone tions remain to be raised on this issue and even more to be answered. Epidemiological findings have unveiled numerous environmental and genetic risk factors, each one contributing to a certain degree to the final account of new CRC cases. Moreover, different trends have been revealed regarding the age of onset of CRC between the two sexes. That, in addition to newly introduced therapeutic approaches for various diseases based on androgens, anti-androgens and anabolic hormones has raised some concerns regarding their possible carcinogenic effects or their synergistic potential with other substances/risk factors, predisposing the individual to CRC. Notably, despite the intense research on experimental settings and population studies, the conclusions regarding the majority of anabolic substances are ambiguous. Some of these indicate the carcinogenic properties of testosterone, dihydrotestosterone (DHT), growth hormone and insulin-like growth factor (IGF) and others, demonstrating their neutral nature or even their protective one, as in the case of vitamin D. Thus, the synergistic nature of anabolic substances with other CRC risk factors (such as type 2 diabetes mellitus, metabolic syndrome and smoking) has emerged, suggesting a more holistic approach.

\section{Contents}

1. Introduction

2. Androgens

3. Anabolic hormones

4. Conclusions

\section{Introduction}

Colorectal cancer (CRC) is the fourth most common type of malignancy after breast, lung and prostate cancer, accounting for 49,190 deaths annually in the USA alone (1). Numerous 
risk factors have been identified, such as age, a family history of CRC, ethnic background (individuals of African descent), a high carbohydrate diet, poor physical activity, obesity and metabolic syndrome, smoking and alcohol abuse (2-5). Originating from epithelial cells at the base of intestinal crypts, the current model of carcinogenesis is that of the adenoma-carcinoma sequence, first described in the 1990s by Bert Vogelstein and Kenneth Kinzler [Fearon and Vogelstein (6) and Kinzler and Vogelstein (7)]. This model proposed a sequential transformation of the normal colorectal epithelium to an adenoma that could further transform into an invasive and metastatic tumor (carcinoma). Mutations in key regions begin to aggregate, turning normal mucosa to an early adenoma and, after a certain point of no return, the accumulated genetic alterations transform it to a carcinoma. Chromosomal instability, microsatellite instability, $\mathrm{CpG}$ island methylation and activating oncogenic mutations in genes such as adenomatous polyposis coli $(A P C), K$-ras and p53 are found to play a key role in this sequence (7-9).

However, as it was found thereafter, the Vogelstein model could explain $90-95 \%$ of CRC cases. The remaining $5-10 \%$ of cases were found to be germline-inherited cancers, such as familial adenomatous polyposis (FAP) and hereditary non-polyposis colorectal cancer (HNPCC). Notably, 2-3\% of all CRC cases are associated with pre-existing inflammation and are referred to as colitis-associated cancer (CAC) (10). In these cases, the activation of nuclear factor (NF) $\kappa \mathrm{B}$ signaling in tumor-associated macrophages (TAMs) leads to the indirect activation of signal transducer and activator of transcription (STAT)3 in pre-malignant intestinal epithelial cells (IECs) (11,12). Even though epidemiologic studies have witnessed a shift towards younger age groups over the past decade, the age group most commonly affected remains that of the middle-aged ( $>50$ years of age) (13), a finding closely related to the Vogelstein model (the accumulation of mutations) $(14,15)$.

Moreover, although CRC is not considered a sex-related malignancy per se, sex differences in incidence rates do exist (16-21). As far as the male population is considered, cancer incidence exhibits two peaks; the first one appears before the age of 35 and the second after the age of 55. On the other hand, in the female population, there is a single peak trend, between 35 and 54 years of age $(22,23)$. Taking into consideration that physical activity performed before or after cancer diagnosis is related to a reduced mortality risk among CRC survivors (24) and is therefore recommended, along with the high prevalence of the use/misuse and abuse of anabolic agents with hormonal activity, such as testosterone, dihydrotestosterone (DHT), finasteride, insulin, insulin-like growth factor-1 (IGF-1) and growth hormone (GH) in the sports community over the past decades (25), a great concern of any possible carcinogenic properties or synergistic effects of the anabolic agents with the already well-studied and identified CRC risk factors has emerged (5). Nonetheless, the data are not consistent: An increasing body of evidence indicates that adequate levels of vitamin $\mathrm{D}$, structurally related to a number of anabolic agents, can indeed protect against carcinogenesis via genomic and non-genomic mechanisms. In addition, the general population experiences uncontrolled multi-chemical exposure from several different sources at doses around or well below regulatory limits (pesticides, food additives, lifestyle products components) $(5,15,26)$ that can contribute to genotoxicity, endocrine disruption, target organ toxicity $(3,4,27-29)$ by affecting systemic mechanistic pathways, such as oxidative stress and cell aging (14,30-32). These, along with the finding that human colorectal adenocarcinomas express specific steroid hormone receptors (33-40), has sparked the interest of the scientific community to unveil any possible pathogenetic mechanisms. Nonetheless, an increasing body of evidence indicates that adequate levels of vitamin D, structurally related to a number of anabolic agents, can indeed protect against carcinogenesis via genomic and non-genomic mechanisms.

\section{Androgens}

An androgen is considered any molecule capable of inducing and maintaining the male phenotype in an organism (male primary and secondary sexual characteristics and fertility) and taking part in the universal outgrowth of the musculoskeletal system and the anabolic shift of the metabolic status (41). Generally, the androgen-producing endocrine glands are able to synthesize five androgens via a sole pathway: Testosterone, dehydroepiandrosterone sulfate (DHEAS), dehydroepiandrosterone (DHEA), androstenedione and androstenediol, the latter of which has both androgenic and estrogenic properties. The molecules that prevail in this category are testosterone (the principal androgen in mammals) and DHT (potent metabolite of testosterones). In fact, they are the only androgens with direct androgenic activity. Other molecules, such as DHEA, due to their inferior potency, have received less attention. In an adult male organism, testosterone is primarily produced by Leydig cells in the testes. In addition, the extra-gonadal synthesis of testosterone and DHT by the adrenal testosterone precursor, DHEA, also occurs (42). Although adrenal androgens represent a minor fraction of the circulating testosterone for an adult male with an intact androgen biosynthesis cascade, they can be the main androgens in a female or a pre-puberty male (43). In the majority of cases, the classical mode of action of androgen superfamily is mediated by the androgen receptor.

Anabolic androogenic steroids (AAS) are used in the treatment of several disorders, such as hypogonadism, cachexia of various etiologies, hypercalcemia, hypercalciuria, in oncology as a supportive treatment and other chronic diseases (44). Since the early 1930s, AAS have been extensively used by amateur and professional athletes and the general public for the improvement of their physical condition and athletic performance (45-49). When used for ergogenic or recreational purposes, the dose levels are usually 5ement of physical condition and athletic performance $(47,50,51)$. At such supraphysiological levels, AAS can cause a number of severe side-effects, including liver dysfunction, renal disorders, cardiotoxicity and potentially, stroke (52). In addition, anti-androgen therapy is also relatively common, having a wide variety of applications ranging from severe conditions (such as the treatment of prostate cancer and polycystic ovary syndrome) to more benign or even aesthetic conditions (such as acne and male pattern hair-loss). Thus, given their wide use in modern society, it is reasonable to scrutinize whether misbalanced androgen levels may possibly have a direct or indirect connection with CRC (41). In the following paragraphs, the 
current data regarding androgens and CRC will be presented according to the clinical significance of the studied molecule.

\section{Natural androgens}

Testosterone. Testosterone, being the most clinically important androgen, has attracted scientific interest from as early as 1986. At that time, studies advocated that androgens played a protective role against CRC. In detail, Izbicki et al (1986) conducted experiments on 40 male rats. They found that chemical castration increased colonic tumor incidence, while testosterone administration following surgical castration produced a borderline statistically significant reduction in tumor incidence $(\mathrm{P}<0.053)$, particularly in the right colon (22). In recent years, hypotestosteronemia (defined as levels of testosterone $<11 \mathrm{nmol} / 1$ or $320 \mathrm{ng} / \mathrm{dl}$ ) was found to contribute to the development of CRC (53). Further data indicating the protective role of testosterone came from studies on patients who received androgen deprivation treatment for prostate cancer. In detail, it was found that the group with the higher risk of developing CRC was that of the orchiectomized male patients followed by patients receiving gonadotropin-releasing hormone $(\mathrm{GnRH})$ agonist therapy (particularly if the treatment was prolonged) (54). On the contrary, there is evidence to suggest that androgens may act as promoters of colon carcinogenesis (2,55-57). Experiments using genetically modified mice, found that in orchiectomized males, the tumor load was lower when there was no administration of male hormone replacement therapy (2). Other researchers have indicated that, at an early stage, androgens may play an active role in the transition from adenoma to carcinoma (6). In contrast to both previous statements, a large study on 4,165 males aged 70-88 years demonstrated that increased testosterone levels were associated neither with an increased nor with a decreased risk of colon cancer risk (58). The same conclusion was achieved by a prospective study of 8,771 males and females from the general population of Denmark, who were followed-up for $>30$ years (59). Whichever the case may be, androgens can be related to CRC either through direct mechanisms (mediated through androgen receptors), indirect mechanisms (smoking and alcohol habits, metabolic syndrome and type 2 diabetes mellitus, altered gut microbiota and increased stress hormones) or even a combination of both (60). Worthy of mention is the fact that regardless of the nature of the study (in vitro, in vivo or epidemiological), a common ground has yet to be found given the opposing data derived from these studies. Thus, in order to reach a consensus on the possible carcinogenetic properties of testosterones and the circumstances under which they appear, and to provide the grounds for a safe comparison between studies, research teams will have to adopt a common methodology as the basis of their experiments (27).

DHEA. Despite being less extensively studied, opposing results have been obtained on this less potent molecule as well. In an observational study on 170 individuals, the plasma levels of dehydroepiandrosterone sulfate were shown to be inversely associated with the risk of developing colon cancer (with a borderline statistical significance) (61). Moreover, another study proposed that DHEA strongly blunts serum deprivation-induced apoptosis. The anti-apoptotic effects of DHEA have been found to be completely reversed by testosterone through the blockade of DHEA receptors, thereby antagonizing its actions (62).
Mode of action. There are namely two modes of action, direct action and indirect action. These are discussed below.

a) Direct action: Androgen receptors (ARs). Steroid hormones, and thus androgens, exert their effects mainly through interactions with specific receptor proteins $(37,56)$. The presence of ARs in human colonic tumors was first shown by Alford et al (34). The gene encoding the AR is located on the $\mathrm{X}$ chromosome. It contains two polymorphic trinucleotide repeat segments that encode polyglutamine (CAG) and polyglycine (GGC) (normally, ranging from 6 to 39 repeats). Surprisingly, only the number of CAG repeats has been found to be associated with misbalanced androgen levels. In fact, studies have demonstrated an inverse association between the number of repeats and the risk of prostate cancer $(63,64)$. According to Hoque et al, the number of these repeats is gradually reduced in prostate cancers (65). Existing data advocate that fewer CAG repeats result in a higher transcription activity of AR, a finding positively associated with prostate cancer $(66,67)$. In parallel, a greater number of repeats are associated with increased serum androgen levels, indicating a protective role of these against CRC $(61,66)$.

Notably, Westberg et al came across a sex-related difference in the association between the number of the CAG repeats and the risk of developing CRC. The association was found to be direct in males, but inverse in females. They concluded that the inverse association observed in females would imply a stimulatory rather than inhibitory influence of AR on androgen production. A possible explanation could be found in the implication of both the AR and the estrogen receptor $\mathrm{b}$ (ERb) in the regulation of serum androgen levels (68). The above-mentioned hypothesis was reinforced by the similar findings of Slattery et al, who analyzed two large case-control studies of CRC. They further found a greater chance of microsatellite instability (MSI) or p53 mutated tumors in the male population when more CAG repeats were present in the $A R$ gene. Their concern was the lack of a common accepted parameter to determine the regulation of androgen levels. It has not yet been established whether the CAG repeat (as suggested by haplotype analysis of the $A R$ gene) or the functionality of the receptor for the specific polymorphism is the most informative variant (64).

The above-mentioned results are in discordance with a following larger scale study of 1,798 CRC cases and 1,810 controls. In that study, the implication of the $A R$ CAG repeat polymorphism in colorectal cancer prognosis was investigated for the first time. Of note, no association was found between the above-mentioned polymorphism and CRC overall or the disease-specific survival rate. As outlined by the authors, the genotyping error rate calculated from the duplicated samples was relatively high for the $A R C A G$ repeat polymorphism (69). A genotyping error occurs when the genotype of an individual observed in the laboratory does not correspond to the individual's true genotype (70). The causes could be categorized as a variation of the DNA sequence, the low quantity or quality of DNA, biochemical artifacts (low quality reagents, poor equipment precision or reliability, Taq polymerase errors, the lack of specificity, electrophoresis artifact) and human error (sample manipulation, experimental error, data handling) (71). Since the main cause of genotyping 
error is human error (71), Rudolph et al concluded that further studies are required to extract solid results (69).

Further attempts to unveil a possible prognostic value of the $A R$ CAG repeat sequence with regards to sex differences have yielded some interesting findings. A recent case-control study of $550 \mathrm{CRC}$ cases and 540 healthy controls concluded that long CAG repeats confer an increased risk of developing $\mathrm{CRC}$ in both sexes along with a poor 5-year survival, while fewer CAG repeats seem to protect against CRC (72). Previous studies have indicated that the CAG repeat length of $A R$ inversely affects its transactivation potential, either through directly altering the receptor's function (73) or indirectly reducing $A R$ messenger in RNA and protein levels (74). Either way, long CAG repeat sequences lead to absence of AR expression, which, in turn, has been linked to tumor size $>5 \mathrm{~cm}$ in diameter and moderate to poor differentiation (at T3-T4 and N1-2 stages). These patients have also demonstrated a great risk of recurrence or metastasis. Notably, the above are found less frequently when there are short CAG repeat sequences and, thus, the normal expression of $A R(72)$.

It should be pointed out that the trans-activating function of AR is dependent on its ligands, the androgens. The receptor participation in controlling cellular differentiation and proliferation in hormone-dependent tissues does not always occur in the same manner (75). Catalano et al shed some light onto this phenomenon. They mentioned two isoforms of the $\mathrm{AR}$; androgen receptor A (AR-A) $(87 \mathrm{kDa})$ and androgen receptor $\mathrm{B}(\mathrm{AR}-\mathrm{B})(110 \mathrm{kDa})$. In the healthy colonic mucosa, both receptors are present; however, in the neoplastic colonic mucosa, only AR-A could be detected. The loss of expression of AR-B and the continuous expression of AR-A was proposed to indicate a loss of cell differentiation (76).

Another category of AR was also discovered; the membrane androgen receptors (mARs). Normally, the actions of the androgens are mediated through intracellular receptors (iARs). mARs seem to mediate opposite actions than iARs, inducing tumor regression (77). Furthermore, the affinity and selectivity of mARs differ among specific androgens (78). Through this receptor, testosterone exerts pro-apoptotic effects in both prostate and colon cancer cells. In human colon cancer cell lines, the activation of the ligand-bound androgen receptor suppresses the transcription of $\beta$-catenin. Consequently, there is a decreased expression of $\beta$-catenin target oncogenes, including cyclin DI (79).

The long-term activation of $\mathrm{mAR}$ by testosterone-albumin conjugated (TAC) treatment has also been linked to the dephosphorylation of protein Kinase B (Akt) both in vitro and in vivo (77). It is closely connected with the invasiveness of colon cancer cells in response to a variety of stimuli [heregulin, P21 (RAC1) activated kinase 1 (PAK1), Sprouty-2 etc.] (80-82), a finding supported through the examination of the upstream regulators of Akt, in particular PI3K. Upon long-term TAC treatment, it is dephosphorylated, leading to reduced cell motility in colon cancer and, consequently, invasiveness. Of note, although testosterone seems to induce p-Akt downregulation when it binds to mARs, iAR bondage induces p-Akt upregulation, even within the same cells. The main target of mAR activation that may regulate cell motility is thought to be vinculin; a cytoskeletal protein which links integrin adhesion molecules to actin. The inhibition or silencing of vinculin via

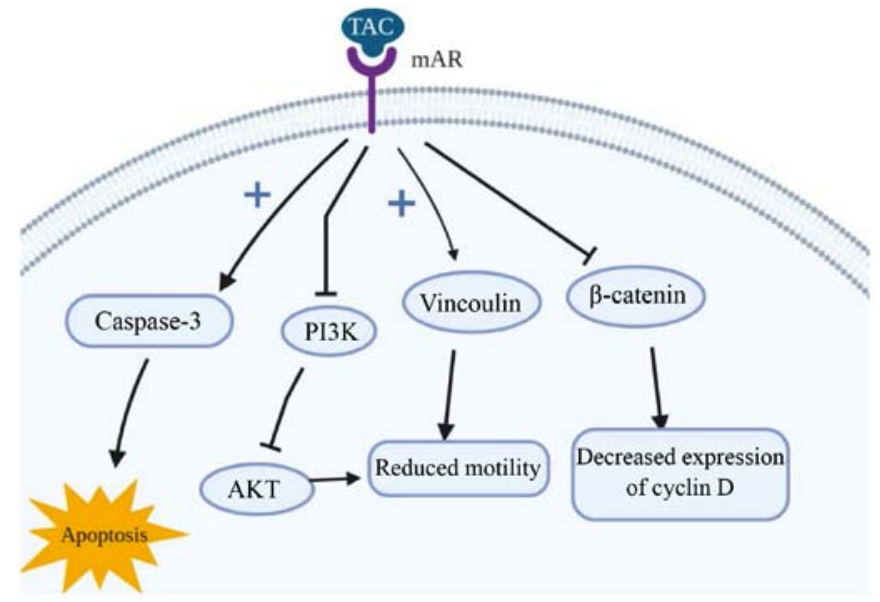

Figure 1. Actions of membrane androgen receptors (mARs). mARs have been found to mediate opposing actions to the intracellular androgen receptors. They induce apoptosis through the activation of caspase-3. Furthermore they phosphorylate vinculin in cancer cells, leading to the inhibition of their migration. The suppression of $\beta$-catenin transcription leads to decreased expression of $\beta$-catenin target oncogenes, including cyclin D1. Finally, the long-term activation of mAR has been linked to the dephosphorylation of $\mathrm{PI} 3 \mathrm{~K}$. As a result, Akt is downregulated and the motility of the colon cancer cells and their invasiveness are reduced. IGF-R, insulin-like growth factor receptor; IRS-1, insulin receptor substrate 1; IGFBPs, insulin-like growth factor binding proteins; ERK, extracellular signal-regulated kinase; VEGF, vascular endothelial growth factor.

the phosphorylation by specific inhibitors, as is the case with activation of mARs, largely reverses both actin reorganization and the inhibition of migration (77). An illustrated representation of the mode of action of mAR is presented in Fig. 1.

Upstream in the AR activation pathway, the role of co-activator-associated arginine methyltransferase 1 (CARM1) is crucial. CARM1 is a protein with arginine-specific histone methyltransferase activity. It primarily binds to the histone and p160 co-activators, leading to the activation of nuclear receptors, ARs included. Thus, it promotes nuclear receptor activity and acts as a molecular switch for gene-specific transcription factors including $\mathrm{p} 53, \mathrm{NF}-\mathrm{kB}$, lymphoid enhancer-binding factor 1 (LEF1)/transcription factor 4 (TCF-4) and E2Fs $(83,84)$. Taking the above into consideration, it is clear that the role of CARM1 is of utmost importance for cell proliferation and survival $(85,86)$. Kim et al reported the overexpression of CARM1 in CRC specimens, but a weak expression in normal mucosal cells. They demonstrated that CARM1 inhibits the p53 response and instead promotes the NF-kB response in Caco2 cells (87). However, the mechanisms involved remain to be fully clarified $(87,88)$.

b) Indirect mode of action. Decreased levels of androgens seem to lead to a net increase in stress hormone levels, such as cortisol, which affect the tumor environment (89). The involvement of the innate immune system in the development of CRC has been demonstrated as well. The neutrophil count is reduced, as found by Chuang et al in castrated males, although it can be restored to normal levels through androgen supplementation (90). Androgens also seem to affect the production and excretion of biliary steroids and bile, compounds that are suggested to act as co-carcinogens $(17,38)$. Lastly, an induction of insulin resistance following androgen deprivation therapy (91) has been linked to increased risk of developing 
CRC (92). The connection between insulin and CRC will be further discussed.

Synthetic anabolic agents. Synthetic anabolic agents are categorized into two categories: Anabolic-androgenic steroids (AAS) and selective androgen receptor modulators (SARMs) (93). The AAS molecules that have thus far been approved as therapeutic agents are testosterone, nortestosterone, dihydrochlormethyltestosterone (DHCMT), metenolon, metandienone, methyltestosterone, oxandrolone, fluoxymesterone, stanozolol, formestane, 5on, metandieno (94). SARMS are non-steroidal alternatives to AAS with the selective activation of the AR in either muscle tissue or bones (93).

A number of adverse effects of these compounds have been described when used either as medicine or as doping agents. As far as AAS's relation to cancer is concerned, a positive association with hepatocellular carcinoma (95), renal cancer (96-98), soft tissue carcinoma (99), adenocarcinoma $(100,101)$ and lymphosarcoma (102) has been found, along with a case report hypothesizing their involvement in leiomyosarcoma (103). SARMs have also been linked to prostate cancer (104). However, to the best of our knowledge, there are currently no data available in the current literature associating any of these compounds with CRC.

\section{Anabolic hormones}

Insulin and insulin receptors (IRs). Insulin is one of the principal anabolic hormones in the majority of animals since it regulates the metabolism of almost all key energy points in favor of their synthesis and storage. The target substances of insulin $\mathrm{k}$ are namely carbohydrates, lipids and proteins. Acting on adipocytes, hepatocytes and muscle cells, induces and maintains to a certain extent, an anabolic state which is described by the synthesis of carbohydrates, fatty acids and proteins, while reducing their degradation. Although a basic requirement is the prior balance between the circulating levels of the target substances and the intracellular ones, for a short period of time, it can overcome the concentration gradient of a substance and induce its endocytosis (105). The role of insulin in CRC was first introduced by the observation that obesity was associated with an increased risk of developing CRC in males. Subsequently, hyperinsulinemia and insulin resistance were linked to obesity and CRC development (106). In a large epidemiological study of almost 25,000 patients with type 2 diabetes mellitus (107) and in a large meta-analysis of 16 studies (108), a direct association between long-term insulin therapy and type 2 diabetes mellitus with an increased risk of developing $\mathrm{CRC}$ was found. It has also been established that CRC survivors with excess amounts of blood insulin have a greater risk of recurrence (109). By contrast, a large registry-based study in Connecticut that included 9,395 patients with CRC (110) and a smaller Norwegian study of 1,194 hospitalized patients with CRC (111), failed to find an association between diabetes and CRC-specific death. It must be stated though, that the latter studies included patients with metastatic CRC as well.

Schoen et al found a statistically significant association between insulin and adenoma status. The association was even stronger with advanced adenomas. The association with adenomatous polyps, the precursor of CRC, confirms a link between insulin and early neoplasia (112). It must be kept in mind that high insulin levels increase serum IGF-1 levels $(113,114)$, a factor which is closely related to carcinogenesis.

To date, two isoforms of IR have been described, differing at the short exon 11 (encodes 12 amino acids). The absence of exon 11 transcripts the IR-A (short isoform), while its presence the IR-B (long isoform) (115). Existing evidence supports that the two IR isoforms play different biological roles. IR-A mostly exerts mitogenic effects and IR-B modulates cell metabolism (116). Abbruzzese et al found a strong IR expression in adenomas and low-grade adenocarcinomas (117). The expression of IR-A has been found in cells that have lost their differentiation, a finding which is in accordance with the presence of this receptor in cancer $(118,119)$.

The expression of $I R$ is mainly considered to be present in epithelial tumor cells [epithelial insulin receptor (EIR)]. However, Heckl et al found the expression of the receptor in other tumor compartments, e.g., the tumor-vasculature [vascular insulin receptor (VIR)]. When 1,580 cases of CRC were examined concerning the expression of the $I R$, differential expression patterns of the $I R$ in tumor cells (EIR) and endothelial cells of tumor vessels (VIR) have been observed. EIR expression is strongly associated with distant metastasis, lymphatic invasion, lymph node metastasis, tumor-specific survival (TSS) and overall survival (OS). Moreover, EIR has been found almost exclusively in the cytoplasm of tumor cells, whereas a (simultaneous) membranous $I R$ expression was less prevalent (120). These findings were further clarified by in vitro experiments by Morcavallo et al, who demonstrated that insulin or IGF-II stimulation induced the phosphorylation-activation of IR-A, which was then internalized from the cell surface. The underlying mechanism was speculated to be a sustained phosphorylation of the receptor, leading to prolonged activation (121).

On the other hand, VIRs are thought to contribute to neovascularization following abduction by elevated insulin levels. VIRs are frequently found in CRC, particularly in left-sided CRCs, and they are significantly associated with tumor invasiveness (120).

From another point of view, insulin resistance in vascular endothelial cells can promote tumor formation, possibly through mechanisms involving chronic inflammation (122). This resistance is characteristic of endothelial dysfunction in obesity and type 2 diabetes (123-126) and was found to promote tumor development. By contrast, there was almost no effect of insulin signaling on intestinal carcinogenesis through epithelial receptors (122).

In order to fully understand the role of insulin in the tumor cascade, special reference must be made to extracellular vesicles (EVs). These are vesicles found in the extracellular space of various cell types. They can be found under normal and pathological conditions $(127,128)$. EVs package biologically active content (including proteins, mRNA and miRNA), which they further transfer to the recipient cells. Due to their action they are considered as mediators of signaling cascades $(129,130)$. EVs are known to mediate various biological cascades relative to cancer, such as the activation of Wnt signaling and the activation of PI3K/Akt signaling (129).

Insulin, similar to other growth factors, induces PI3K/Akt signaling (131-133). PI3K/Akt-positive CRC cells react to PI3K/Akt signaling by producing EVs which, in turn, amplify 
the proliferative signal in other CRC cells in the close environment. The deeper in the proliferative core the EVs reach, the greater the benefit for the tumor, as in these areas the transfer of nutrients/growth factors would have been otherwise impossible. Thus, EVs amplify the proliferative signal and aid cancer progression (134).

$I G F$ and its receptor $(I G F-R)$. IGF is a hormone that serves as the mediator of growth hormone $(\mathrm{GH})$-stimulated somatic growth, as well as a mediator of $\mathrm{GH}$-independent anabolic responses in a number of cells and tissues, while it is also associated with mitogenesis, cell survival and differentiation (135-142). In detail, IGF-1 promotes cell cycle progression and inhibits apoptosis either by triggering other growth factors or by interacting with pathways which have an established role in carcinogenesis and cancer promotion (142). Ma et al stated that there is an increase in IGF-1 levels in patients with CRC (143), while other studies have advocated the overexpression of IGF-R, as well (144-147). In accordance with this, several studies have linked elevated plasma IGF-1 and IGF-1R downstream signaling to an enhanced risk of colorectal neoplasia and a poor survival (148-152). Furthermore, Peters et al found that IGF-1 was closely related to the expression of the proliferation marker $\mathrm{Ki}-67$ (153). $\mathrm{Ki}-67$ is a nuclear protein that is active only in dividing cells and absent in cells locked in G0 phase. This is a logical outcome when taking into consideration that IGF-1 can stimulate the expression of cyclin D1, a molecule that accelerates the progression of the cell cycle from G1 to $\mathrm{S}$ phase (154). However, there is no prognostic relevance of Ki-67 in CRC, regardless of the stage of disease $(155,156)$. Through a reverse line of thought, octreotide, a molecule that lowers the IGF-1 concentration, has been shown to attenuate the growth rate of tumor cells in vivo (157).

The expression of $I G F-2$ is also highly associated with tumor stage. The association was speculated when it was found that autocrine IGF-2 production and consequent IGF-R activation increased tumor growth and reduced apoptosis (153). Thus, it is plausible that, when IGF-1 or IGF-2 is present, an IGF-1R self-stimulation will produce an autocrine/paracrine loop in CRC. However, no prognostic effect of IGF-1 and IGF-2 has been proven (153).

A family of six circulating proteins termed insulin-like growth factor binding proteins (IGFBPs) has been found to interfere with the action of IGF. Thus, their involvement in CRC must be investigated, as well. They act either as tumor suppressors by limiting IGFs activity (158) or as inhibitors of cancer growth through IGF-independent mechanisms (159). High IGFBP2 plasma levels were found by Liou et al to be independently associated with a reduced overall survival (OS) of patients with CRC (160). By contrast, IGFBP3 has been shown to be inversely associated with $\mathrm{CRC}$, as its plasma levels were found to be lower in those patients (143). Notably, IGFBP-3 can either oppose or enhance the biologic action of IGF-I through direct bondage to IGF-I or indirectly to IGF-R (161).

In a prospective cohort study of 210 patients with CRC, IGF-1 expression was shown to be closely associated with tumor size and the depth of invasion. However, it was stated that a shift of investigation towards the IGF-1/IGFBP-3 ratio is warranted, as it better describes the biological effects of IGF-1 (152). A nested case control study of males in the
Physician's Health Study demonstrated an increased risk of CRC in subjects with high IGF-I levels. The risk was decreased when high IGFBP-3 levels were measured (143). A study of 460 patients was carried out to further examine the association between IGF-I and the IGF-I/IGFBP-3 ratio with colorectal adenomatous polyps. A statistically significant positive association was found, with greater odds ratio when the case group was limited to advanced adenomas. This finding indicates a possible stimulation of non-advanced adenomas towards advanced adenomas (112).

Closer attention must be paid to the IGF-R, as it has been stated that it contributes to resistance to cytotoxic (162), radiation (163) and targeted therapies (164-166). Indeed, the silencing of the receptor increases the intracellular drug concentration (such as oxaliplatin and vincristine); an effect mediated via the PI3K/Akt pathway (167). A progressive increase in $I G F-1 R$ expression occurs in normal colonic mucosa, while it transits to adenomatous, as well as in the transition from adenomatous to carcinomatous tissue (147). Peters et al have confirmed a strong expression of the IGF-1 receptor in $>99 \%$ of all CRC cell lines of their experiments (153).

Following its activation, IGF-R induces multiple intracellular mechanisms, as shown in Fig. 2. It induces the transcription of the vascular endothelial growth factor (VEGF) gene $(168,169)$, upregulates the anti-apoptotic protein, Bcl-xL (170) and inhibits the action of $\beta$-catenin (through PI3K/Akt activation) (171). From another perspective, Nahor et al demonstrated that the tumor-suppression genes $p 63$ and $p 73$ inhibit the IGF-1R promoter, reducing the endogenous IGF-1R levels in a dose-dependent manner. Through this mechanism, it was proposed that they control colon cancer proliferation (172).

The pro-oncogenic activities of IGF-1R are solely mediated through its proximal downstream effectors: Insulin receptor substrate 1 (IRS-1) and 2 (IRS-2) $(173,174)$. IRS-1 expression appears to be inversely associated with CRC differentiation. However, it may be upregulated in both primary and metastatic human CRC, a finding that has not been observed in normal colonic epithelium (175). It has been further supported that the upregulation of IRS-1 can occur directly from androgens (64). IRS-2 mRNA and protein expression have a positive association with the transition from normal colorectal epithelium to adenoma and adenocarcinoma. Furthermore, IRS-2 overexpression promotes the invasiveness of CRC cells. It activates the oncogenic PI3K/Akt pathway and at the same time reduces cell adhesion (176). Finally, IRS-1 and IRS-2 polymorphisms have been independently associated with the risk of developing $\mathrm{CRC}$ in a direct manner (177).

The above-mentioned findings are further supported by the action of NT157 in murine and human CRC cells. NT157 is a molecule that, through bondage to an allosteric site of the IGF-1R, it induces a conformational change. As a result, the receptor is dissociated from IRS1 and IRS2 proteins. Consequently, IGF-1R stronger interacts with the adaptor protein Shc, leading to an enhanced activation of extracellular signal-regulated kinase (ERK). Indeed, experiments have confirmed that NT157 activates ERK1/2, without activating Akt (178).

Vitamin D. Vitamin D regulates cellular functions, such as differentiation and proliferation in normal and malignant 


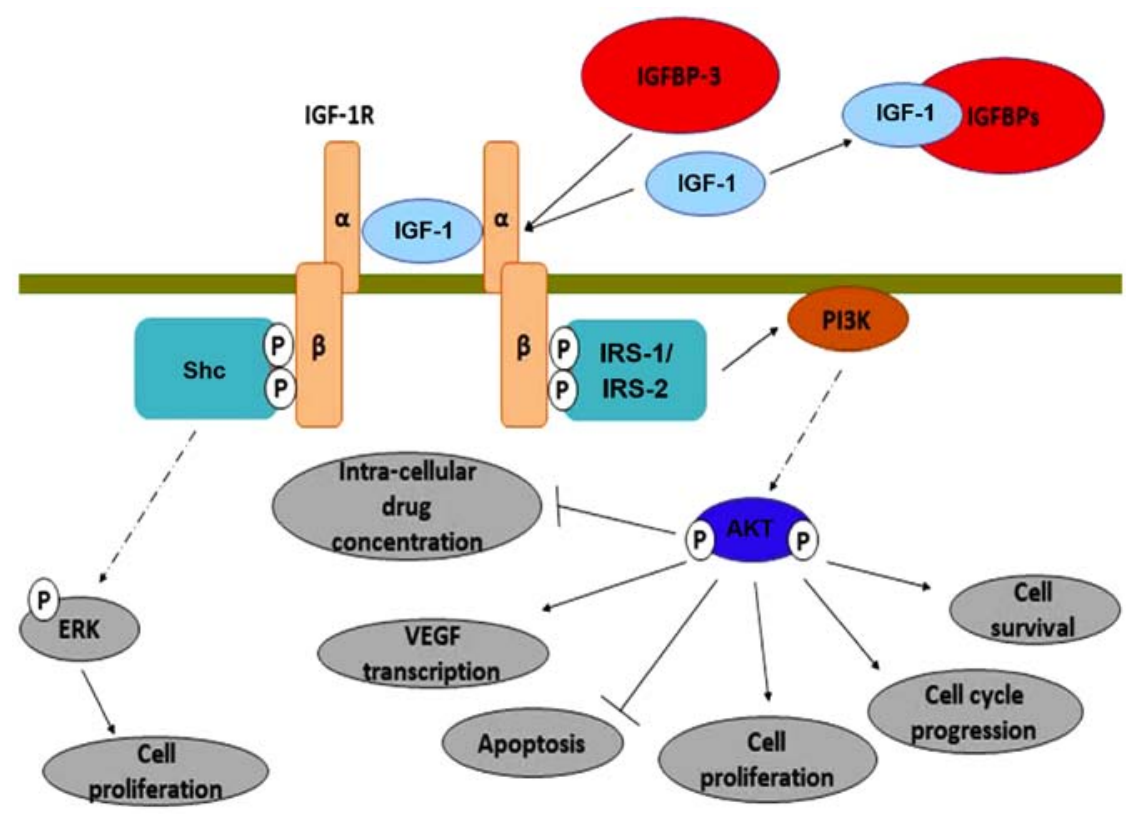

Figure 2. Mechanisms mediated through IGF-1/IGF-1R. The activation of IGF-1R takes place following the bondage of IGF-1 (or IGF-2) to the extracellular part of the receptor. IGF-1 plasma levels, and thus IGF-1R activation, are reduced by the IGFBPs. However, IGFBP-3 can act as an enhancer of the IGF-1 activity when it is bonded to the receptor and not directly to IGF-1. Following its activation, IGF-1R induces the phosphorylation of IRS-1,2 molecules, which they further activate the PI3K-Akt pathway. Consequently, there is induction of cell survival, cell cycle progression, cell proliferation and VEGF transcription. At the same time, apoptosis is inhibited and the cell gains resistance against cancer therapies. Even when IRS-1,2 molecules are silenced, the activation of IGF-1R leads to increased cell proliferation through the activation of Shc-ERK pathway. IRS-1, insulin receptor substrate 1; IGFBPs, insulin-like growth factor binding proteins; ERK, extracellular signal-regulated kinase; VEGF, vascular endothelial growth factor.

tissues. It also regulates cell adhesion in tumor cells and modifies tumor angiogenesis, invasion and metastasis along with decreasing oxidative DNA damage (179). Vitamin D deficiency has been associated with various cancer types $(180,181)$.

Vitamin D first attracted scientific attention after an inverse association was observed between solar UV-B exposure and CRC incidence in both genres (182). As it has been well-established, UV-B radiation is essential for the production of vitamin $\mathrm{D} 3$, which after two steps becomes $1,25-(\mathrm{OH})_{2}$-vitamin $\mathrm{D}$ (calcitriol), the most active component $(183,184)$.

The study by Boscoe and Schymura on 3.1 million individuals from the northern part of the USA supported that low levels of vitamin D can induce the progression of CRC, although no association was found with disease onset. Their proposal was based upon a higher death rate which occurred during the winter months (when levels of vitamin D are markedly reduced) (182). Feskanich et al found an inverse association of 25-OH-vitamin D and CRC in observation in the female population, although only in areas where high levels of UV-B are available (185). In fact, levels of 25-OH-vitamin D $>20 \mathrm{ng} / \mathrm{ml}$ have been advocated to provide protection against CRC (186). If levels of 25-OH-vitamin D are $>82 \mathrm{ng} / \mathrm{ml}$, then it is estimated that the cancer incidence is decreased by $50 \%$ (187). However, no association has been found between 1,25- $\mathrm{OH}_{2}$-vitamin D and CRC (185); a finding disputing the results of two previous studies $(188,189)$.

Calcitriol has been found to reduce tumorigenesis in rats $(190,191)$ and proliferation in both normal and premalignant human rectal epithelioma (192), as well as in human colorectal cell lines, while it stimulates their differentiation (193-196). Vandewalle et al proposed that an increased expression of vitamin $D$ receptor (VDR) may lead to cell differentiation and growth inhibition either through calcitriol or through non-calcemic analogs (195). The mechanisms behind the protective role of vitamin D against CRC are multiple and can be categorized into genomic and non-genomic mechanisms, as discussed below.

Genomic mechanisms. The genomic mechanisms are mediated through the VDR as is shown in Fig. 3. Following the bondage of $1,25-\mathrm{OH}_{2}$-vitamin $\mathrm{D}$ to the receptor, the complex is dimerized with another receptor, the retinoid $\mathrm{X}$ receptor (RXR). This heterodimer targets specific areas in genes called vitamin D response elements (VDREs) (197). As a result, several miRNAs are affected through up- or down-regulation. These miRNAs have been speculated to suppress oncogenes or enhance the expression of tumor suppressor genes. For example, vitamin D can induce the promoter of miR-627. This gene has been inversely linked with CRC, as its decreased expression (an aftermath of reduced levels of vitamin D) has been found to promote cancer (198).

Further action of vitamin D in human colon tumor cells leads to the upregulation of the potent anti-angiogenic factor, thrombospondin 1 (199). The upregulation of the transcription of the Wnt-inhibitors, the DICKKOPF-1 and DICKKOPF-4 genes, has also been linked with the action of calcitriol (200). There are data to suggest that calcitriol regulates apoptosis as well (201). Following treatment of colorectal cell lines with $1,25-\mathrm{OH}_{2}$-vitamin $\mathrm{D}$, it was found that apoptosis was triggered through secreted protein acidic and rich in cysteine (SPARC)-induced VDR synthesis (202). In another cell line, treatment with calcitriol induced the mRNA expression of the pro-apoptotic protein, G0S2 (G0/G1 switch gene) (203). Furthermore, WAF1 and KIP1 were found to be up-regulated, leading to cell-cycle arrest in G1 phase $(201,204,205)$. 


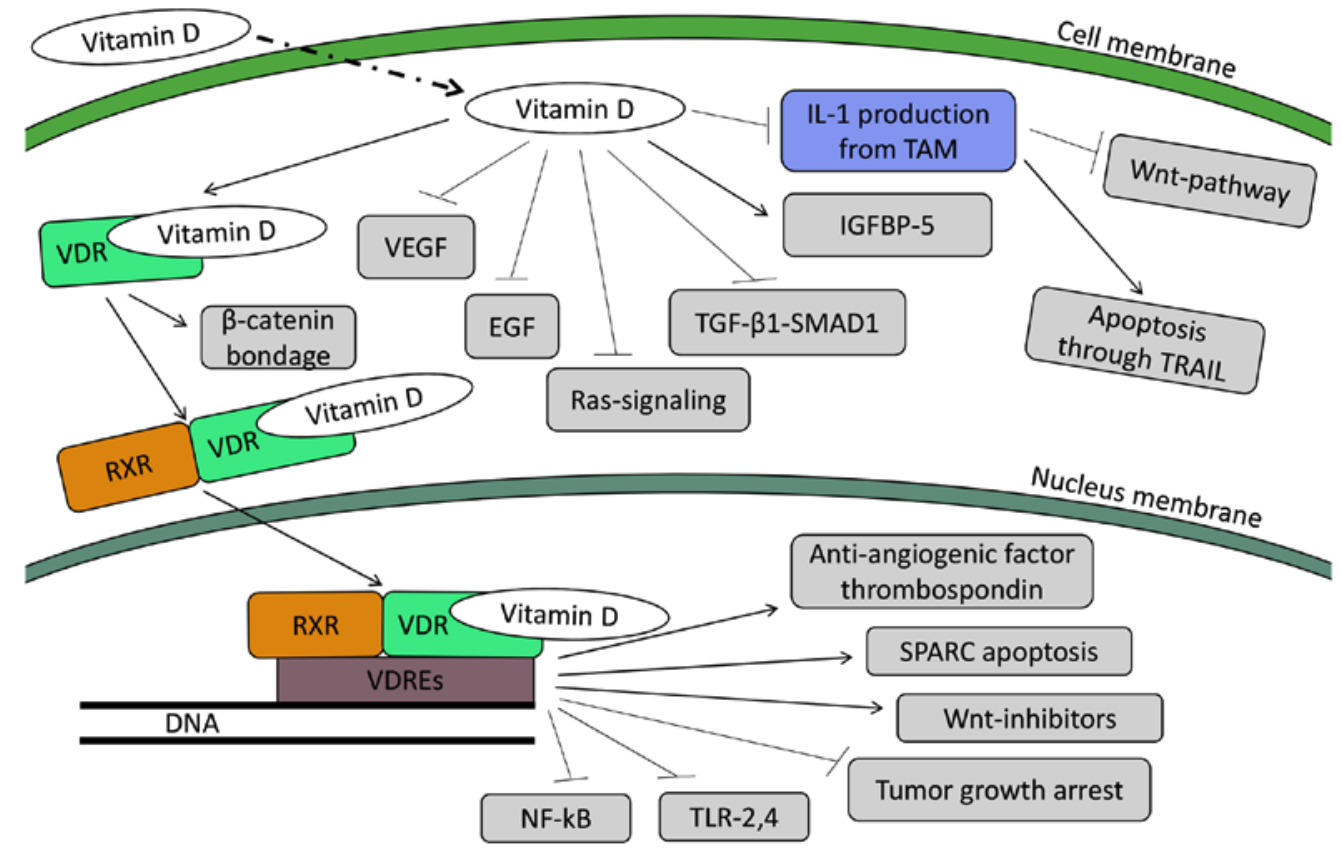

Figure 3. Mechanisms mediated through vitamin D. The insertion of vitamin D into a colorectal cell triggers multiple pathways; both in the cytoplasm (non-genomic actions of vitamin D) and in the nucleus (genomic actions of vitamin D). Through its non-genomic actions, vitamin D halts tumor development through he inhibition of VEGF, EGF, Ras-signaling and TGF- $\beta$. At the same it induces IGFBP-5 production, diminishing this way the cancer-promoting effects of IGF-1,2. Also of importance is the reprogram of TAMs, which results in lower levels of IL-1 production. Consequently, the Wnt-pathway is halted, while apoptosis through the TRAIL pathway is triggered. Followin bondage with the VDR it can either bind $\beta$-catenin (inhibiting its translocation to the nucleus) or, after being heterodimerized with the RXR, translocates to the nucleus. In the nucleus, the complex vitamin D-VDR-RXR binds to VDREs gene sequences. As an aftermath, the induction of the anti-angiogenic factor thrombospondin 1 occurs, as well as apoptosis through the SPARC pathway and transcription of Wnt-inhibitors. Finally, the inhibition of NF- $\mathrm{BB}$ and TLR-2,4, while tumor growth is halted (through inhibition of CDK-Is, cyclin D1, c-myc, etc). ERK, extracellular signal-regulated kinase; VEGF, vascular endothelial growth factor; TAMs, tumor-associated macrophages; VDR, vitamin D receptor; RXR, retinoid $\mathrm{X}$ receptor; VDREs, vitamin D response elements; SPARC, secreted protein acidic and rich in cysteine.

Other studies have demonstrated the effects of calcitriol on tumor growth. Through the induction of cyclin-dependent kinase inhibitors, such as p21, p27 and cystatin D and the inhibition of pro-proliferative genes, including $c$-my and cyclin Dl, tumor growth is halted (198). $N F-\kappa B$ is another target family of genes (fundamental for the cancer cell survival) which are downregulated by vitamin D (206). Finally, the reduction of colon cancer cell lines has been suggested following the decreased expression of Toll-like receptor (TLR)2 and 4 on human monocytes (207).

Non genomic mechanisms. Apart from the genomic action through the nuclear receptor, calcitriol can bind to membrane receptors in certain tissues (including the intestines), leading to non-genomic, non-nuclear actions (208-211). It has been well documented that in CRC, APC mutation is by far one of the most common, allowing various downstream pro-oncogenic pathways to upshift. One of these pathways is the Wnt pathway, where $\beta$-catenin acts as a transcriptional co-regulator, cooperating with transcription factors of the T-cell factor (TCF) family to determine gene expression $(212,213)$. Pendás-Franco et al described the protective action of calcitriol in colon cancer cells, according to which it induces VDR to bind with $\beta$-catenin and restrain it from translocating to the nucleus and inducing the expression of pro-carcinogenic genes (200). Furthermore, vitamin D-related compounds have been found to induce the production of IGFBP-5. These molecules bind both with IGF-1 and IGF-2, suppressing the stimulating effect of these molecules (214).
Furthermore, vitamin D seems to be able to reprogram the tumor-associated macrophages (TAMs) in a manner that halts their tumor-promoting actions (215), probably by inhibiting STAT1 activity. As a result, there is no production of interleukin (IL)-1 from the latter, rendering the tumor colon cells sensitive to apoptosis through the TRAIL pathway (216). In parallel, due to the lack of $I L-1 \beta$ expression, the Wnt pathway is deactivated (215).

Further observations of a crosstalk between vitamin D and TGF- $\beta 1 /$ SMAD1 signaling in the growth inhibition of human colon cancer-derived cells has shown that this interaction halts tumor growth by blocking the expression of cell cycle proteins and inhibiting the action of cyclins D1, D2, D3 and E (217). It has also been found to inhibit mitogenic Ras signaling, as well as the epidermal growth factor (EGF) (218-220). Furthermore, Ben-Shoshan et al exhibited an inhibition of vascular endothelial growth factor (VEGF) in colon cancer cell lines by vitamin D (221).

Last but not least, the association of vitamin D with calcium must be examined. It seems they exert a synergistic effect in reducing CRC incidence. This was first described in Apcmin mouse models by Harris and Go (222) and later on by Lappe et al who carried a clinical trial on post-menopausal women in Nebraska. They concluded that although calcium alone reduced the all-cancer incidence by $44 \%$, when accompanied by vitamin $\mathrm{D}$ the reduction reached $77 \%$ (223). 
Table I. Association between anabolic hormones and CRC.

\begin{tabular}{|c|c|c|c|}
\hline Substance & Relation to CRC & Author (year)/(Refs.) & Nature of the study \\
\hline \multirow[t]{9}{*}{ Testosterone } & $\begin{array}{l}\text { Physiological testosterone levels induce reduction } \\
\text { in tumor incidence especially in right colon }\end{array}$ & Izbicki et al (1986) (22) & In vivo \\
\hline & \multirow{2}{*}{$\begin{array}{l}\text { Hypotestosteronemia contributes to CRC } \\
\text { development }\end{array}$} & Gould and Petty (53) & \multirow{6}{*}{$\begin{array}{l}\text { In vivo } \\
\text { Epidemiological } \\
\text { In vivo }\end{array}$} \\
\hline & & Gillesen et al (54) & \\
\hline & \multirow[t]{4}{*}{ Androgens may act as promoters of CRC } & Amos-Landgraf et al (2) & \\
\hline & & Izbicki et al (1983) (55) & \\
\hline & & Mehta et al (56) & \\
\hline & & Moon and Fricks (57) & \\
\hline & $\begin{array}{l}\text { Androgens may play an active role in } \\
\text { the adenoma }=>\text { carcinoma sequence }\end{array}$ & Fearon and Vogelstein (6) & In vivo \\
\hline & $\begin{array}{l}\text { Increased testosterone levels have no connection } \\
\text { with CRC }\end{array}$ & $\begin{array}{l}\text { Hyde } \text { et al (58) } \\
\text { Orsted } \text { et al (59) }\end{array}$ & Epidemiological \\
\hline \multirow{2}{*}{$\begin{array}{l}\text { Dehydroepiandrosterone } \\
\text { (DHEA) }\end{array}$} & DHEA levels are inversely associated with & Alberg et al (61) & Epidemiological \\
\hline & CRC risk & Anagnostopoulou et al (62) & In vitro \\
\hline \multirow{5}{*}{$\begin{array}{l}\text { Androgen receptors } \\
\text { (ARs) }\end{array}$} & \multirow{2}{*}{$\begin{array}{l}\text { Number of CAG repeats is linearly correlated } \\
\text { with CRC in men and inversely in women }\end{array}$} & Slattery et al (2005) (64) & \multirow[t]{2}{*}{ Epidemiological } \\
\hline & & Westberg et al (68) & \\
\hline & Number of CAG repeats is independent from & Rudolph et al (69) & Epidemiological \\
\hline & CRC survival rate & & \\
\hline & Long CAG repeats & Huang et al (72) & Epidemiological \\
\hline
\end{tabular}

Synthetic

anabolic agents

(AAS and SARMs)
Increased risk for $\mathrm{CRC}$ in both sexes

Poor 5-year survival

High $\mathrm{T}$ and $\mathrm{N}$ stage

Few CAG repeats protect against CRC

mARs seem to mediate opposite actions than iARs Gu et al (2011) (77)

AASs positive correlation with a variety of cancers (among which is adenocarcinoma)

SARMs are linked with prostate cancer but not with CRC

Watanabe and

Kobayashi (95)

Martorana et al (97)

Insulin

Long-term insulin therapy/ high blood insulin

levels

Increased risk of CRC

Greater risk of CRC recurrence

No connection between diabetes and CRC-specific Polednak (110)

death

EIR expression results to distant metastasis, $\quad$ Heckl et al (120)

lymphatic invasion, lymph node metastasis, tumor Morcavallo et al (121) specific survival and overall survival

receptor (EIR)

Vascular insulin receptor VIR is frequently found in CRC, especially
(VIR)
in left-sided CRCs, and associated with tumo invasiveness

Insulin-like growth High levels of IGF-1 are related with CRC

factor 1 (IGF-1)

IGF-1 expression is associated with tumor size and depth of invasion

IGFBPs
High IGFBP2 positively associated with reduced overall survival in CRC
Rosner and Khan (96)

Bryden et al (98)

Zahm and Fraumeni (99)

Bronson and Matherne (102) In vivo

Froehner et al (103)

Chacon and Monga (104)

Yang et al (107)

Larsson et al (108)

Flood et al (109)

Jullumstrø et al (111)

Heckl et al (120)

In vitro

Epidemiological

Epidemiological

Epidemiological

Epidemiological

In vitro

Epidemiological

Soubry et al (149)

Lee et al (148)

Ma et al (143)

Ollberding et al (150)

Giovannucci (2001) (151)

Shiratsuchi et al (152)

Shiratsuchi et al (152)

Liou et al (160)
Epidemiological

In vivo

In vitro

Epidemiological

Epidemiological 
Table I. Continued.

\begin{tabular}{|c|c|c|c|}
\hline Substance & Relation to CRC & Author (year)/(Refs.) & Nature of the study \\
\hline \multirow[t]{9}{*}{ Vitamin D } & $\begin{array}{l}\text { Low levels of vitamin D can induce the } \\
\text { progression of CRC }\end{array}$ & $\begin{array}{l}\text { Boscoe and Schymura } \\
\text { (182) }\end{array}$ & Epidemiological \\
\hline & $\begin{array}{l}\text { Levels of } 25-\mathrm{OH} \text {-vitamin } \mathrm{D}>20 \mathrm{ng} / \mathrm{ml} \text { can protect } \\
\text { against CRC }\end{array}$ & $\begin{array}{l}\text { Braun et al }(186) \\
\text { Gorham et al }(187)\end{array}$ & Epidemiological \\
\hline & $\begin{array}{l}\text { Levels of } 25-\mathrm{OH} \text {-vitamin } \mathrm{D}>82 \mathrm{ng} / \mathrm{ml} \text { cancer } \\
\text { incidence is decreased by } 50 \%\end{array}$ & & \\
\hline & $\begin{array}{l}\text { Vitamin D can induce the promoter of } \\
\text { onco-protective miR- } 627\end{array}$ & Padi et al (198) & In vivo \\
\hline & $\begin{array}{l}\text { Vitamin D in human colon tumor cells } \\
\text { up-regulates the potent anti-angiogenic factor } \\
\text { thrombospondin } 1\end{array}$ & $\begin{array}{l}\text { Fernandez-Garcia et al } \\
\text { (199) }\end{array}$ & In vitro \\
\hline & $\begin{array}{l}\text { Vitamin D up-regulates the transcription } \\
\text { of the Wnt-inhibitors DICKKOPF-1 and } \\
\text { DICKKOPF-4 }\end{array}$ & Pendás-Franco et al (200) & In vitro \\
\hline & Vitamin D regulates apoptosis through SPARC & $\begin{array}{l}\text { Ylikomi et al (201) } \\
\text { Taghizadeh et al (202) }\end{array}$ & In vitro \\
\hline & $\begin{array}{l}\text { Vitamin D down-regulates NF- } \mathrm{B} \text {, TLR2 and } \\
\text { TLR4 }\end{array}$ & $\begin{array}{l}\text { Liu et al (206) } \\
\text { Kim and Brasitus } \\
(2001)(208)\end{array}$ & In vitro \\
\hline & $\begin{array}{l}\text { Vitamin D may be able to reprogram the } \\
\text { tumor-associated macrophages (TAM) and halt } \\
\text { their tumor-promoting actions }\end{array}$ & Kaler et al (215) & In vitro \\
\hline Growth hormone $(\mathrm{GH})$ & Growth hormone suppresses p53, PTEN, and APC & $\begin{array}{l}\text { Brown-Borg et al (231) } \\
\text { Chesnokova et al (232) } \\
\text { Morin et al (233) } \\
\text { Clevers and Nusse (234) }\end{array}$ & $\begin{array}{l}\text { Epidemiological } \\
\text { In vivo } \\
\text { In vivo }\end{array}$ \\
\hline
\end{tabular}

CRC, colorectal cancer; IGF, insulin-like growth factor; IGFBP, insulin-like growth factor binding protein; SPARC, secreted protein acidic and rich in cysteine; TLR, Toll-like receptor; PTEN, phosphatase and tensin homolog; APC, adenomatous polyposis coli.

Growth hormone $(G H)$. Human growth hormone (hGH) or somatotropin, is a peptide-hormone secreted mainly by somatotropic cells within the lateral wings of the anterior pituitary. After entering the bloodstream it reaches its target organs (namely the liver, muscles, bones and adipose tissue) binding to its receptor [growth hormone receptor (GHR)] and thus inducing its anabolic properties through the activation of the mitogen activated protein kinase (MAPK)/ERK and JAK/STAT pathways $(224,225)$. It has been well documented that $\mathrm{GH}$ plays a key role in longitudinal growth during childhood, while maintaining various important metabolic functions throughout life (promoting lipolysis, protein synthesis and gluconeogenesis, while reducing glucose uptake from the liver) (226). Of note though, GH action is slightly more sophisticated. Apart from its direct action, an indirect one through the production of IGF-1 also takes place, representing an important part of GH physiology. In fact, a potent stimulus of IGF-1 production is the GH per se. Moreover, the tissues producing IGF-1 (the liver $75 \%$ and the peripheral tissues) are indeed the target organs of GH (227). However, it has been proven that GH is not only synthesized in the pituitary, but also in various other tissues, such as the large intestine, prostate and breast $(228,229)$. In this case however, $\mathrm{GH}$ lacks the endocrine potential and its action is mainly restricted to an autocrine or paracrine manner (230).
Due to its proliferative properties, GH has attracted reasonable attention for its carcinogenic potential. In fact, various studies have demonstrated that $\mathrm{GH}$ is indeed able to create a favorable microenvironment for tumor cells. In detail, $G H$ overexpression is linked to an increased risk of malignancies (231), while its downregulation is linked to a carcinoprotective state. As for CRC risk per se, $\mathrm{GH}$ has been proven to act as a tumor promoter in colon tissue by suppressing p53 (232), phosphatase and tensin homolog ( $P T E N)$ and $A P C(8)$, while it has also been proven that colon cancer cells overexpress GHR (232). In fact, upregulated $\mathrm{GH}$ has been exhibited to increase ERK phosphorylation and to decrease $A P C$ expression (232). It is known that a decreased $A P C$ expression promotes the nuclear accumulation of $\beta$-catenin, which in turn increases Wnt signaling through the activation of pro-proliferative genes $(233,234)$. Thus, even though it is difficult to estimate the exact concentration for any given age above which $\mathrm{GH}$ poses its carcinogenic effect on colon cells, there is enough evidence supporting that the ability of GH to change the microenvironment of tumor cells can have a synergistic effect with other CRC risk factors (such as intestinal dysbiosis, smoking etc.), shifting the balance towards tumor survival and proliferation (235). 


\section{Conclusions}

After 30 years of intense research on CRC and its biological behavior, only few facts have withstood the test of time, all revealing the impressive complexity and diversity of this entity. In fact, this is the case for the association between CRC and anabolic substances. Driven by epidemiological observations on both sexes, a time pattern of CRC onset has been found. However, studies thus far have failed to reach a consensus regarding the direct connection between androgens and the risk of developing CRC, as some studies have indicated a negative effect, while others have pointed out a neutral or even a protective one (Table I). In the case of androgens, the androgen receptor (the principal mediator of their action) has been proven to be altered in CRC in contrast to healthy individuals. Moreover, anabolic substances are also put to scrutiny given the intense presence of such substances in patients with CRC (namely IGF-1). However, no direct or well-studied indirect mode of action on CRC pathogenesis has been found for both classes. Thus, more studies are needed that will focus on both epidemiologic data (that will try to investigate how the use of anabolic agents, androgens included, alters CRC statistics) and the elucidation of molecular pathways implicated in CRC, in order to allow the extraction of solid conclusions. In addition, as passive everyday life exposure to hazardous chemicals could affect traditional clinical risk factors and act synergistically, the patterns of living and consumers' trends should also be taken into consideration when evaluating CRC.

\section{Acknowledgements}

Not applicable.

\section{Funding}

No funding was received.

\section{Availability of data and materials}

Not applicable.

\section{Authors' contributions}

JT conceived and designed the study. TK and TKN researched the literature, performed analysis of data and drafted the manuscript. DAS, CT and AT made substantial contributions to the conception of the study and critically revised the article for important intellectual content. MS, JS, TMS made substantial contributions to the design of the study and critically revised the article for important intellectual content. All authors have read and approved the final manuscript.

\section{Ethics approval and consent to participate}

Not applicable.

\section{Patient consent for publication}

Not applicable.

\section{Competing interests}

DAS is the Editor-in-Chief for the journal, but had no personal involvement in the reviewing process, or any influence in terms of adjudicating on the final decision, for this article. The other authors declare that they have no competing interests.

\section{References}

1. Roshan MH, Tambo A and Pace NP: The role of testosterone in colorectal carcinoma: Pathomechanisms and open questions. EPMA J 7: 22, 2016.

2. Amos-Landgraf JM, Heijmans J, Wielenga MC, Dunkin E, Krentz KJ, Clipson L, Ederveen AG, Groothuis PG, Mosselman S, Muncan V, et al: Sex disparity in colonic adenomagenesis involves promotion by male hormones, not protection by female hormones. Proc Natl Acad Sci USA 111: 16514-16519, 2014.

3. Docea AO, Goumenou M, Calina D, Arsene AL, Dragoi CM, Gofita E, Pisoschi CG, Zlatian O, Stivaktakis PD, Nikolouzakis TK, et al: Adverse and hormetic effects in rats exposed for 12 months to low dose mixture of 13 chemicals: RLRS part III. Toxicol Lett 310: 70-91, 2019.

4. Tsatsakis AM, Docea AO, Calina D, Buga AM, Zlatian O, Gutnikov S, Kostoff RN and Aschner M: Hormetic Neurobehavioral effects of low dose toxic chemical mixtures in real-life risk simulation (RLRS) in rats. Food Chem Toxicol 125: 141-149, 2019.

5. Tsatsakis AM, Kouretas D, Tzatzarakis MN, Stivaktakis P, Tsarouhas K, Golokhvast KS, Rakitskii VN, Tutelyan VA, Hernandez AF, Rezaee R, et al: Simulating real-life exposures to uncover possible risks to human health: A proposed consensus for a novel methodological approach. Hum Exp Toxicol 36: 554-564, 2017.

6. Fearon ER and Vogelstein B: A genetic model for colorectal tumorigenesis. Cell 61: 759-767, 1990.

7. Kinzler KW and Vogelstein B: Lessons from hereditary colorectal cancer. Cell 87: 159-170, 1996.

8. Vogelstein B and Kinzler KW: Cancer genes and the pathways they control. Nat Med 10: 789-799, 2004.

9. Nikolouzakis TK, Vassilopoulou L, Fragkiadaki P, Mariolis Sapsakos T, Papadakis GZ, Spandidos DA, Tsatsakis AM and Tsiaoussis J: Improving diagnosis, prognosis and prediction by using biomarkers in CRC patients (Review). Oncol Rep 39: 2455-2472, 2018

10. Terzic J, Grivennikov S, Karin E and Karin M: Inflammation and colon cancer. Gastroenterology 138: 2101-2114.e5, 2010.

11. Greten FR, Eckmann L, Greten TF, Park JM, Li ZW, Egan LJ, Kagnoff MF and Karin M: IKKbeta links inflammation and tumorigenesis in a mouse model of colitis-associated cancer. Cell 118: 285-296, 2004.

12. Grivennikov S, Karin E, Terzic J, Mucida D, Yu GY, Vallabhapurapu S, Scheller J, Rose-John S, Cheroutre H, Eckmann L, et al: IL-6 and Stat 3 are required for survival of intestinal epithelial cells and development of colitis-associated cancer. Cancer Cell 15: 103-113, 2009.

13. Chlebowski RT, Wactawski-Wende J, Ritenbaugh C, Hubbell FA, Ascensao J, Rodabough RJ, Rosenberg CA, Taylor VM, Harris R, Chen C, et al; Women's Health Initiative Investigators: Estrogen plus progestin and colorectal cancer in postmenopausal women. N Engl J Med 350: 991-1004, 2004.

14. Tsoukalas D, Fragkiadaki P, Docea AO, Alegakis AK, Sarandi E, Thanasoula M, Spandidos DA, Tsatsakis A, Razgonova MP and Calina D: Discovery of potent telomerase activators: Unfolding new therapeutic and anti-aging perspectives. Mol Med Rep 20: 3701-3708, 2019

15. Tsatsakis AM, Docea AO and Tsitsimpikou C: New challenges in risk assessment of chemicals when simulating real exposure scenarios; simultaneous multi-chemicals' low dose exposure. Food Chem Toxicol 96: 174-176, 2016.

16. Potter JD and McMichael AJ: Large bowel cancer in women in relation to reproductive and hormonal factors: A case-control study. J Natl Cancer Inst 71: 703-709, 1983.

17. McMichael AJ and Potter JD: Reproduction, endogenous and exogenous sex hormones, and colon cancer: A review and hypothesis. J Natl Cancer Inst 65: 1201-1207, 1980. 
18. Young JL Jr, Asire AJ and Polalack ES (eds): SEER Program: Cancer incidence and mortality in the United States: 1973-1976. US Department of Health, Education, and Welfare, NCI, p67, 1978.

19. Burbank F: Patterns in cancer mortality in the United States: 1950-1967. Natl Cancer Inst Monogr 71: 1-594, 1971.

20. Haenszel W and Correa P: Cancer of the colon and rectum and adenomatous polyps. A review of epidemiologic findings. Cancer 28: 14-24, 1971.

21. Howell MA: The association between colorectal cancer and breast cancer. J Chronic Dis 29: 243-261, 1976

22. Izbicki JR, Wambach G, Hamilton SR, Harnisch E, Hogenschurz R, Izbicki W and Kusche J: Androgen receptors in experimentally induced colon carcinogenesis. J Cancer Res Clin Oncol 112: 39-46, 1986

23. Nikolouzakis TK, Stivaktakis PD, Apalaki P, Kalliantasi K, Sapsakos TM, Spandidos DA, Tsatsakis A, Souglakos J and Tsiaoussis J: Effect of systemic treatment on the micronuclei frequency in the peripheral blood of patients with metastatic colorectal cancer. Oncol Lett 17: 2703-2712, 2019.

24. Qiu S, Jiang C and Zhou L: Physical activity and mortality in patients with colorectal cancer: a meta-analysis of prospective cohort studies. Eur J Cancer Prev: April 5, 2019.

25. Gabrielsen JS, Najari BB, Alukal JP and Eisenberg ML: Trends in Testosterone Prescription and Public Health Concerns. Urol Clin North Am 43: 261-271, 2016.

26. Georgiadis N, Tsarouhas K, Tsitsimpikou C, Vardavas A, Rezaee R, Germanakis I, Tsatsakis A, Stagos D and Kouretas D: Pesticides and cardiotoxicity. Where do we stand? Toxicol Appl Pharmacol 353: 1-14, 2018

27. Margina D, Nițlescu G, Ungurianu A, Mesnage R, Goumenou M, Sarigiannis DA, Aschner M, Spandidos DA, Renieri EA, Hernández AF and Tsatsakis A: Overview of the effects of chemical mixtures with endocrine disrupting activity in the context of real life risk simulation (RLRS): an integrative approach (Review). World Acad Sci J (In press).

28. Veremchuk LV, Tsarouhas K, Vitkina TI, Mineeva EE, Gvozdenko TA, Antonyuk MV, Rakitskii VN, Sidletskaya KA, Tsatsakis AM and Golokhvast KS: Impact evaluation of environmental factors on respiratory function of asthma patients living in urban territory. Environ Pollut 235: 489-496, 2018.

29. Zafiropoulos A, Tsarouhas K, Tsitsimpikou C, Fragkiadaki P, Germanakis I, Tsardi M, Maravgakis G, Goutzourelas N, Vasilaki F, Kouretas D, et al: Cardiotoxicity in rabbits after a low-level exposure to diazinon, propoxur, and chlorpyrifos. Hum Exp Toxicol 33: 1241-1252, 2014.

30. Tsatsakis A, Docea AO, Constantin C, Calina D, Zlatian O, Nikolouzakis TK, Stivaktakis PD, Kalogeraki A, Liesivuori J, Tzanakakis G, et al: Genotoxic, cytotoxic, and cytopathological effects in rats exposed for 18 months to a mixture of 13 chemicals in doses below NOAEL levels. Toxicol Lett: Sep 12, 2019 (Epub ahead of print).

31. Ozcagli E, Kara M, Kotil T, Fragkiadaki P, Tzatzarakis MN, Tsitsimpikou C, Stivaktakis PD, Tsoukalas D, Spandidos DA, Tsatsakis AM, et al: Stanozolol administration combined with exercise leads to decreased telomerase activity possibly associated with liver aging. Int J Mol Med 42: 405-413, 2018.

32. Kadıŏlu E, Taçoy G, Özçağlı E, Okyay K, Akboğa MK, Cengel A and Sardas S: The role of oxidative DNA damage and GSTM1, GSTT1, and hOGG1 gene polymorphisms in coronary artery disease risk. Anatol J Cardiol 16: 931-938, 2016.

33. McClendon JE, Appleby D, Claudon DB, Donegan WL and DeCosse JJ: Colonic neoplasms: Tissue estrogen receptor and carcinoembryonic antigen. Arch Surg 112: 240-241, 1977.

34. Alford TC, Do HM, Geelhoed GW, Tsangaris NT and Lippman ME: Steroid hormone receptors in human colon cancers. Cancer 43: 980-984, 1979.

35. Sica V, Contieri E, Nola E, Bova R, Papaleo G and Puca GA: Estrogen and progesterone binding proteins in human colorectal cancer. A preliminary characterization of estradiol receptor. Tumori 67: 307-314, 1981.

36. Odagiri E, Jibiki K, Demura R, Shinozaki H, Nakamura S, Demura $\mathrm{H}$ and Suzuki H: Steroid receptors and the distribution of IR-carcinoembryonic antigen in colonic cancer. Dis Colon Rectum 27: 787-791, 1984.

37. Jacobson HL: Present status of steroid hormone receptor in large bowel cancer. Prog Cancer Res Ther 29: 367, 1984.

38. Izbicki JR, Schmitz R, Hoppen HO, Izbicki W and Troidl H: Effects of steroid hormone therapy on primarily xenotransplanted human colorectal adenocarcinomas. J Cancer Res Clin Oncol 108: 345-350, 1984.
39. Wobbes T, Beex LVAM and Koenders AMJ: Estrogen and progestin receptors in colonic cancer? Dis Colon Rectum 27: 591-592, 1984.

40. Bucci L, Salfi R, Meraviglia F and Delric G: Hormonal receptors in colorectal cancers (abstract). Second European Conference on Clinical Oncology and Cancer Nursing 8: 41-98, 1983.

41. Handelsman DJ: Androgen Physiology, Pharmacology and Abuse. In: Endotext [Internet]. Feingold KR, Anawalt B, Boyce A, et al (eds). MDText.com, Inc., South Dartmouth, MA, 2000.

42. Hiort O, Holterhus PM and Nitsche EM: Physiology and pathophysiology of androgen action. Baillieres Clin Endocrinol Metab 12: 115-132, 1998.

43. Guyton AC and Hall JE: Textbook of medical physiology. 11th edition. Elsevier Saunders, Philladelphia, PA, 2006.

44. Brenu EW, McNaughton L and Marshall-Gradisnik SM: Is there a potential immune dysfunction with anabolic androgenic steroid use?: A review. Mini Rev Med Chem 11: 438-445, 2011.

45. Tsarouhas K, Kioukia-Fougia N, Papalexis P, Tsatsakis A, Kouretas D, Bacopoulou F and Tsitsimpikou C: Use of nutritional supplements contaminated with banned doping substances by recreational adolescent athletes in Athens, Greece. Food Chem Toxicol 115: 447-450, 2018

46. Tsitsimpikou C, Chrisostomou N, Papalexis P, Tsarouhas K, Tsatsakis A and Jamurtas A: The use of nutritional supplements among recreational athletes in Athens, Greece. Int J Sport Nutr Exerc Metab 21: 377-384, 2011.

47. Vasilaki F, Tsitsimpikou C, Tsarouhas K, Germanakis I,Tzardi M, Kavvalakis M, Ozcagli E, Kouretas D and Tsatsakis AM: Cardiotoxicity in rabbits after long-term nandrolone decanoate administration. Toxicol Lett 241: 143-151, 2016.

48. Baggish AL, Weiner RB, Kanayama G, Hudson JI, Picard MH, Hutter AM Jr and Pope HG Jr: Long-term anabolic-androgenic steroid use is associated with left ventricular dysfunction. Circ Heart Fail 3: 472-476, 2010

49. Tsitsimpikou C, Tsarouhas K, Spandidos DA and Tsatsakis AM: Detection of stanozolol in the urine of athletes at a pg level: The possibility of passive exposure. Biomed Rep 5: 665-666, 2016.

50. Sattler FR, Jaque SV, Schroeder ET, Olson C, Dube MP, Martinez C, Briggs W, Horton R and Azen S: Effects of pharmacological doses of nandrolone decanoate and progressive resistance training in immunodeficient patients infected with human immunodeficiency virus. J Clin Endocrinol Metab 84: 1268-1276, 1999

51. Santos MA, Oliveira CV and Silva AS: Adverse cardiovascular effects from the use of anabolic-androgenic steroids as ergogenic resources. Subst Use Misuse 49: 1132-1137, 2014.

52. Bonetti A, Tirelli F, Catapano A, Dazzi D, Dei Cas A, Solito F, Ceda G, Reverberi C, Monica C, Pipitone S, et al: Side effects of anabolic androgenic steroids abuse. Int J Sports Med 29: 679-687, 2008.

53. Gould DC and Petty R: The male menopause: does it exist? For: Some men need investigation and testosterone treatment. West J Med 173: 76-78, 2000

54. Gillessen S, Templeton A, Marra G, Kuo YF, Valtorta E and Shahinian VB: Risk of colorectal cancer in men on long-term androgen deprivation therapy for prostate cancer. J Natl Cancer Inst 102: 1760-1770, 2010 .

55. Izbicki JR, Schmitz R, Kamran D and Izbicki W: Androgens as promoters of colon carcinogenesis. Cancer Detect Prev 6: 355-362, 1983.

56. Mehta RG, Fricks CM and Moon RC: Androgen receptors in chemically-induced colon carcinogenesis. Cancer 45 (Suppl): 1085-1089, 1980

57. Moon RC and Fricks CM: Influence of gonadal hormones and age on 1,2-dimethylhydrazine-induced colon carcinogenesis. Cancer 40 (Suppl): 2502-2508, 1977.

58. Hyde Z, Flicker L, McCaul KA, Almeida OP, Hankey GJ, Chubb SA and Yeap BB: Associations between testosterone levels and incident prostate, lung, and colorectal cancer. A population-based study. Cancer Epidemiol Biomarkers Prev 21: $1319-1329,2012$

59. Orsted DD, Nordestgaard BG and Bojesen SE: Plasma testosterone in the general population, cancer prognosis and cancer risk: A prospective cohort study. Ann Oncol 25: 712-718, 2014.

60. Koliarakis I, Psaroulaki A, Nikolouzakis TK, Kokkinakis M, Sgantzos MN, Goulielmos G, Androutsopoulos VP, Tsatsakis A and Tsiaoussis J: Intestinal microbiota and colorectal cancer: a new aspect of research. J BUON 23: 1216-1234, 2018. 
61. Alberg AJ, Gordon GB, Hoffman SC, Comstock GW and Helzlsouer KJ: Serum dehydroepiandrosterone and dehydroepiandrosterone sulfate and the subsequent risk of developing colon cancer. Cancer Epidemiol Biomarkers Prev 9: 517-521, 2000.

62. Anagnostopoulou V, Pediaditakis I, Alkahtani S, Alarifi SA, Schmidt EM, Lang F, Gravanis A, Charalampopoulos I and Stournaras C: Differential effects of dehydroepiandrosterone and testosterone in prostate and colon cancer cell apoptosis: The role of nerve growth factor (NGF) receptors. Endocrinology 154: 2446-2456, 2013.

63. Ferro P, Catalano MG, Raineri M, Reato G, dell'Eva R, Risio M, Foà R, Fortunati $\mathrm{N}$ and Pfeffer U: Somatic alterations of the androgen receptor CAG repeat in human colon cancer delineate a novel mutation pathway independent of microsatellite instability. Cancer Genet Cytogenet 123: 35-40, 2000.

64. Slattery ML, Sweeney C, Murtaugh M, Ma KN, Wolff RK, Potter JD, Caan BJ and Samowitz W: Associations between ERalpha, ERbeta, and AR genotypes and colon and rectal cancer. Cancer Epidemiol Biomarkers Prev 14: 2936-2942, 2005

65. Hoque A, Albanes D, Lippman SM, Spitz MR, Taylor PR, Klein EA, Thompson IM, Goodman P, Stanford JL, Crowley JJ, et al: Molecular epidemiologic studies within the Selenium and Vitamin E Cancer Prevention Trial (SELECT). Cancer Causes Control 12: 627-633, 2001.

66. Krithivas K, Yurgalevitch SM, Mohr BA, Wilcox CJ, Batter SJ, Brown M, Longcope C, McKinlay JB and Kantoff PW: Evidence that the CAG repeat in the androgen receptor gene is associated with the age-related decline in serum androgen levels in men. J Endocrinol 162: 137-142, 1999.

67. Ding D, Xu L, Menon M, Reddy GP and Barrack ER: Effect of a short CAG (glutamine) repeat on human androgen receptor function. Prostate 58: 23-32, 2004.

68. Westberg L, Baghaei F, Rosmond R, Hellstrand M, Landén M, Jansson M, Holm G, Björntorp P and Eriksson E: Polymorphisms of the androgen receptor gene and the estrogen receptor beta gene are associated with androgen levels in women. J Clin Endocrinol Metab 86: 2562-2568, 2001.

69. Rudolph A, Shi H, Försti A, Hoffmeister M, Sainz J, Jansen L, Hemminki K, Brenner H and Chang-Claude J: Repeat polymorphisms in ESR2 and AR and colorectal cancer risk and prognosis: Results from a German population-based case-control study. BMC Cancer 14: 817, 2014.

70. Bonin A, Bellemain E, Bronken Eidesen P, Pompanon F, Brochmann $\mathrm{C}$ and Taberlet $\mathrm{P}$ : How to track and assess genotyping errors in population genetics studies. Mol Ecol 13: 3261-3273, 2004.

71. Pompanon F, Bonin A, Bellemain E and Taberlet P: Genotyping errors: Causes, consequences and solutions. Nat Rev Genet 6 : $847-859,2005$

72. Huang R, Wang G, Song Y, Wang F, Zhu B, Tang Q, Liu Z, Chen Y, Zhang Q, Muhammad S, et al: Polymorphic CAG Repeat and Protein Expression of Androgen Receptor Gene in Colorectal Cancer. Mol Cancer Ther 14: 1066-1074, 2015.

73. Chamberlain NL, Driver ED and Miesfeld RL: The length and location of CAG trinucleotide repeats in the androgen receptor N-terminal domain affect transactivation function. Nucleic Acids Res 22: 3181-3186, 1994.

74. Choong CS, Kemppainen JA, Zhou ZX and Wilson EM: Reduced androgen receptor gene expression with first exon CAG repeat expansion. Mol Endocrinol 10: 1527-1535, 1996.

75. Ferro P, Catalano MG, Dell'Eva R, Fortunati N and Pfeffer U: The androgen receptor $\mathrm{CAG}$ repeat: A modifier of carcinogenesis? Mol Cell Endocrinol 193: 109-120, 2002.

76. Catalano MG, Pfeffer U, Raineri M, Ferro P, Curto A, Capuzzi P, Corno F, Berta L and Fortunati N: Altered expression of androgen-receptor isoforms in human colon-cancer tissues. Int J Cancer 86: 325-330, 2000.

77. Gu S, Papadopoulou N, Nasir O, Föller M, Alevizopoulos K, Lang F and Stournaras C: Activation of membrane androgen receptors in colon cancer inhibits the prosurvival signals Akt/bad in vitro and in vivo and blocks migration via vinculin/actin signaling. Mol Med 17: 48-58, 2011.

78. Gu S, Papadopoulou N, Gehring EM, Nasir O, Dimas K, Bhavsar SK, Föller M, Alevizopoulos K, Lang F and Stournaras C: Functional membrane androgen receptors in colon tumors trigger pro-apoptotic responses in vitro and reduce drastically tumor incidence in vivo. Mol Cancer 8: 114, 2009.

79. Chesire DR and Isaacs WB: Ligand-dependent inhibition of beta-catenin/TCF signaling by androgen receptor. Oncogene 21: 8453-8469, 2002.
80. Yoshioka T, Nishikawa Y, Ito R, Kawamata M, Doi Y, Yamamoto Y, Yoshida M, Omori Y, Kotanagi H, Masuko T, et al: Significance of integrin $\alpha v \beta 5$ and erbB3 in enhanced cell migration and liver metastasis of colon carcinomas stimulated by hepatocyte-derived heregulin. Cancer Sci 101: 2011-2018, 2010.

81. Holgren C, Dougherty U, Edwin F, Cerasi D, Taylor I, Fichera A, Joseph L, Bissonnette M and Khare S: Sprouty-2 controls c-Met expression and metastatic potential of colon cancer cells: Sprouty/c-Met upregulation in human colonic adenocarcinomas. Oncogene 29: 5241-5253, 2010.

82. Huynh N, Liu KH, Baldwin GS and He H: P21-activated kinase 1 stimulates colon cancer cell growth and migration/invasion via ERK- and AKT-dependent pathways. Biochim Biophys Acta 1803: 1106-1113, 2010.

83. Teyssier C, Ou CY, Khetchoumian K, Losson R and Stallcup MR: Transcriptional intermediary factor 1alpha mediates physical interaction and functional synergy between the coactivator-associated arginine methyltransferase 1 and glucocorticoid receptor-interacting protein 1 nuclear receptor coactivators. Mol Endocrinol 20: 1276-1286, 2006.

84. Chen D, Ma H, Hong H, Koh SS, Huang SM, Schurter BT, Aswad DW and Stallcup MR: Regulation of transcription by a protein methyltransferase. Science 284: 2174-2177, 1999.

85. Koh SS, Li H, Lee YH, Widelitz RB, Chuong CM and Stallcup MR: Synergistic coactivator function by coactivator-associated arginine methyltransferase (CARM) 1 and beta-catenin with two different classes of DNA-binding transcriptional activators. J Biol Chem 277: 26031-26035, 2002.

86. El Messaoudi S, Fabbrizio E, Rodriguez C, Chuchana P, Fauquier L, Cheng D, Theillet C, Vandel L, Bedford MT and Sardet C: Coactivator-associated arginine methyltransferase 1 (CARM1) is a positive regulator of the Cyclin E1 gene. Proc Natl Acad Sci USA 103: 13351-13356, 2006.

87. Kim YR, Lee BK, Park RY, Nguyen NT, Bae JA, Kwon DD and Jung C: Differential CARM1 expression in prostate and colorectal cancers. BMC Cancer 10: 197, 2010.

88. Ilboudo S, Fouche E, Rizzati V, Toé AM, Gamet-Payrastre L and Guissou PI: In vitro impact of five pesticides alone or in combination on human intestinal cell line Caco-2. Toxicol Rep 1: 474-489, 2014.

89. Carroll RE, Goodlad RA, Poole AJ, Tyner AL, Robey RB, Swanson SM and Unterman TG: Reduced susceptibility to azoxymethane-induced aberrant crypt foci formation and colon cancer in growth hormone deficient rats. Growth Horm IGF Res 19: 447-456, 2009.

90. Chuang KH, Altuwaijri S, Li G, Lai JJ, Chu CY, Lai KP, Lin HY, Hsu JW, Keng P, Wu MC, et al: Neutropenia with impaired host defense against microbial infection in mice lacking androgen receptor. J Exp Med 206: 1181-1199, 2009

91. Mårin P, Krotkiewski M and Björntorp P: Androgen treatment of middle-aged, obese men: Effects on metabolism, muscle and adipose tissues. Eur J Med 1: 329-336, 1992.

92. Lin JH and Giovannucci E: Sex hormones and colorectal cancer: What have we learned so far? J Natl Cancer Inst 102: 1746-1747, 2010.

93. Thevis M and Schänzer W: Synthetic anabolic agents: Steroids and nonsteroidal selective androgen receptor modulators. In: Doping in Sports: Biochemical Principles, Effects and Analysis. Handbook of Experimental Pharmacology. Thieme D and Hemmersbach P (eds). Vol 195. Springer, Berlin, Heidelberg, pp99-126, 2010.

94. Joseph JF and Parr MK: Synthetic androgens as designer supplements. Curr Neuropharmacol 13: 89-100, 2015.

95. Watanabe S and Kobayashi Y: Exogenous hormones and human cancer. Jpn J Clin Oncol 23: 1-13, 1993.

96. Rosner F and Khan MT: Renal cell carcinoma following prolonged testosterone therapy. Arch Intern Med 152: 426, 429 , 1992.

97. Martorana G, Concetti S, Manferrari F and Creti S: Anabolic steroid abuse and renal cell carcinoma. J Urol 162: 2089-2089, 1999.

98. Bryden AAG, Rothwell PJN and O'Reilly PH: Anabolic steroid abuse and renal-cell carcinoma. Lancet 346: 1306-1307, 1995.

99.Zahm SH and Fraumeni JF Jr: The epidemiology of soft tissue sarcoma. Semin Oncol 24: 504-514, 1997.

100. Nourbakhsh M, Golestani A, Zahrai M, Modarressi MH, Malekpour Z and Karami-Tehrani F: Androgens stimulate telomerase expression, activity and phosphorylation in ovarian adenocarcinoma cells. Mol Cell Endocrinol 330: 10-16, 2010. 
101.McKeown-Eyssen G: Epidemiology of colorectal cancer revisited: Are serum triglycerides and/or plasma glucose associated with risk? Cancer Epidemiol Biomarkers Prev 3: 687-695, 1994.

102. Bronson FH and Matherne CM: Exposure to anabolic-androgenic steroids shortens life span of male mice. Med Sci Sports Exerc 29: 615-619, 1997.

103. Froehner M, Fischer R, Leike S, Hakenberg OW, Noack B and Wirth MP: Intratesticular leiomyosarcoma in a young man after high dose doping with oral-turinabol: A case report. Cancer 86: 1571-1575, 1999.

104. Chacon A and Monga M: Medical management of benign prostatic hyperplasia. Geriatr Nephrol Urol 9: 39-48, 1999.

105.Dimitriadis G, Mitrou P, Lambadiari V, Maratou E and Raptis SA: Insulin effects in muscle and adipose tissue. Diabetes Res Clin Pract 93 (Suppl 1): S52-S59, 2011.

106. Giovannucci $\mathrm{E}$ and Michaud D: The role of obesity and related metabolic disturbances in cancers of the colon, prostate, and pancreas. Gastroenterology 132: 2208-2225, 2007.

107. Yang YX, Hennessy S and Lewis JD: Insulin therapy and colorectal cancer risk among type 2 diabetes mellitus patients. Gastroenterology 127: 1044-1050, 2004.

108. Larsson SC, Orsini N, Brismar K and Wolk A: Diabetes mellitus and risk of bladder cancer: A meta-analysis. Diabetologia 49: 2819-2823, 2006

109. Flood A, Mai V, Pfeiffer R, Kahle L, Remaley AT, Lanza E and Schatzkin A: Elevated serum concentrations of insulin and glucose increase risk of recurrent colorectal adenomas. Gastroenterology 133: 1423-1429, 2007.

110. Polednak AP: Comorbid diabetes mellitus and risk of death after diagnosis of colorectal cancer: A population-based study. Cancer Detect Prev 30: 466-472, 2006.

111. Jullumstrø E, Kollind M, Lydersen S and Edna TH: Diabetes mellitus and outcomes of colorectal cancer. Acta Oncol 48: 361-367, 2009

112. Schoen RE, Weissfeld JL, Kuller LH, Thaete FL, Evans RW, Hayes RB and Rosen CJ: Insulin-like growth factor-I and insulin are associated with the presence and advancement of adenomatous polyps. Gastroenterology 129: 464-475, 2005

113. LeRoith D, Baserga R, Helman L and Roberts CT Jr: Insulin-like growth factors and cancer. Ann Intern Med 122: 54-59, 1995

114. Sandhu MS, Dunger DB and Giovannucci EL: Insulin, insulin-like growth factor-I (IGF-I), IGF binding proteins, their biologic interactions, and colorectal cancer. J Natl Cancer Inst 94: 972-980, 2002.

115. Siddle K: Signalling by insulin and IGF receptors: Supporting acts and new players. J Mol Endocrinol 47: R1-R10, 2011.

116. Mosthaf L, Grako K, Dull TJ, Coussens L, Ullrich A and McClain DA: Functionally distinct insulin receptors generated by tissue-specific alternative splicing. EMBO J 9: 2409-2413, 1990.

117. Abbruzzese C, Diodoro MG, Sperduti I, Mileo AM, Pattaro G, De Salvo L, Cosimelli M, Perrotti N and Paggi MG: Detection of phosphorylated insulin receptor in colorectal adenoma and adenocarcinoma: Implications for prognosis and clinical outcome. J Cell Physiol 230: 562-567, 2015.

118. Frasca F, Pandini G, Scalia P, Sciacca L, Mineo R, Costantino A, Goldfine ID, Belfiore A and Vigneri R: Insulin receptor isoform A, a newly recognized, high-affinity insulin-like growth factor II receptor in fetal and cancer cells. Mol Cell Biol 19: 3278-3288, 1999.

119. Kosaki A and Webster NJ: Effect of dexamethasone on the alternative splicing of the insulin receptor mRNA and insulin action in HepG2 hepatoma cells. J Biol Chem 268: 21990-21996, 1993.

120. Heck1 SM, Pellinghaus M, Krüger S, Bosselmann C, Wilhelm F, Behrens HM, Schreiber S and Röcken C: Epithelial insulin receptor expression-prognostic relevance in colorectal cancer. Oncotarget 9: 37497-37508, 2018

121. Morcavallo A, Genua M, Palummo A, Kletvikova E, Jiracek J, Brzozowski AM, Iozzo RV, Belfiore A and Morrione A: Insulin and insulin-like growth factor II differentially regulate endocytic sorting and stability of insulin receptor isoform A. J Biol Chem 287: 11422-11436, 2012.

122. Wang X, Häring MF, Rathjen T, Lockhart SM, Sørensen D, Ussar S, Rasmussen LM, Bertagnolli MM, Kahn CR and Rask-Madsen C: Insulin resistance in vascular endothelial cells promotes intestinal tumour formation. Oncogene 36: 4987-4996, 2017.

123. Laakso M, Edelman SV, Brechtel G and Baron AD: Impaired insulin-mediated skeletal muscle blood flow in patients with NIDDM. Diabetes 41: 1076-1083, 1992.
124. Steinberg HO, Chaker H, Leaming R, Johnson A, Brechtel G and Baron AD: Obesity/insulin resistance is associated with endothelial dysfunction. Implications for the syndrome of insulin resistance. J Clin Invest 97: 2601-2610, 1996.

125.Rask-Madsen C, Ihlemann N, Krarup T, Christiansen E, Kober L, Nervil Kistorp C and Torp-Pedersen C: Insulin therapy improves insulin-stimulated endothelial function in patients with type 2 diabetes and ischemic heart disease. Diabetes 50: 2611-2618, 2001

126. Tabit CE, Shenouda SM, Holbrook M, Fetterman JL, Kiani S, Frame AA, Kluge MA, Held A, Dohadwala MM, Gokce N, et al: Protein kinase C- $\beta$ contributes to impaired endothelial insulin signaling in humans with diabetes mellitus. Circulation 127: 86-95, 2013

127. Simpson RJ, Lim JW, Moritz RL and Mathivanan S: Exosomes: Proteomic insights and diagnostic potential. Expert Rev Proteomics 6: 267-283, 2009.

128. Gangoda L and Mathivanan S: Cortactin enhances exosome secretion without altering cargo. J Cell Biol 214: 129-131, 2016.

129. Gangoda L, Boukouris S, Liem M, Kalra H and Mathivanan S: Extracellular vesicles including exosomes are mediators of signal transduction: Are they protective or pathogenic? Proteomics 15: 260-271, 2015

130. Silantyev AS, Falzone L, Libra M, Gurina OI, Kardashova KS, Nikolouzakis TK, Nosyrev AE, Sutton CW, Mitsias PD and Tsatsakis A: Current and Future Trends on Diagnosis and Prognosis of Glioblastoma: From Molecular Biology to Proteomics. Cells 8: 8, 2019.

131. Taniguchi CM, Emanuelli B and Kahn CR: Critical nodes in signalling pathways: Insights into insulin action. Nat Rev Mol Cell Biol 7: 85-96, 2006.

132. Huang XF and Chen JZ: Obesity, the PI3K/Akt signal pathway and colon cancer. Obes Rev 10: 610-616, 2009.

133. Matsuzaki H, Daitoku H, Hatta M, Tanaka K and Fukamizu A: Insulin-induced phosphorylation of FKHR (Foxo1) targets to proteasomal degradation. Proc Natl Acad Sci USA 100: 11285-11290, 2003.

134. Liem M, Ang CS and Mathivanan S: Insulin Mediated Activation of PI3K/Akt Signalling Pathway Modifies the Proteomic Cargo of Extracellular Vesicles. Proteomics 17: 17, 2017.

135. Baserga R: The insulin-like growth factor I receptor: A key to tumor growth? Cancer Res 55: 249-252, 1995.

136. Párrizas $M$ and LeRoith D: Insulin-like growth factor-1 inhibition of apoptosis is associated with increased expression of the bcl-xL gene product. Endocrinology 138: 1355-1358, 1997.

137. Wang L, Ma W, Markovich R, Lee WL and Wang PH: Insulin-like growth factor I modulates induction of apoptotic signaling in H9C2 cardiac muscle cells. Endocrinology 139: 1354-1360, 1998.

138. Remacle-Bonnet MM, Garrouste FL, Heller S, André F, Marvaldi JL and Pommier GJ: Insulin-like growth factor-I protects colon cancer cells from death factor-induced apoptosis by potentiating tumor necrosis factor alpha-induced mitogen-activated protein kinase and nuclear factor kappaB signaling pathways. Cancer Res 60: 2007-2017, 2000.

139. Liu B, Fang M, Lu Y, Mendelsohn J and Fan Z: Fibroblast growth factor and insulin-like growth factor differentially modulate the apoptosis and G1 arrest induced by anti-epidermal growth factor receptor monoclonal antibody. Oncogene 20: 1913-1922, 2001.

140. Ryan PD and Goss PE: The emerging role of the insulin-like growth factor pathway as a therapeutic target in cancer. Oncologist 13: 16-24, 2008.

141. Pollak M: The insulin and insulin-like growth factor receptor family in neoplasia: An update. Nat Rev Cancer 12: 159-169, 2012.

142.Islam MA, Hooiveld GJEJ, van den Berg JHJ, van der Velpen V, Murk AJ, Rietjens IMCM and van Leeuwen FXR: Soy supplementation: Impact on gene expression in different tissues of ovariectomized rats and evaluation of the rat model to predict (post)menopausal health effect. Toxicol Rep 5: 1087-1097, 2018.

143. Ma J,Pollak MN, Giovannucci E, Chan JM, Tao Y,Hennekens CH and Stampfer MJ: Prospective study of colorectal cancer risk in men and plasma levels of insulin-like growth factor (IGF)-I and IGF-binding protein-3. J Natl Cancer Inst 91: 620-625, 1999.

144. Lahm H, Suardet L, Laurent PL, Fischer JR, Ceyhan A, Givel JC and Odartchenko N: Growth regulation and co-stimulation of human colorectal cancer cell lines by insulin-like growth factor I, II and transforming growth factor alpha. Br J Cancer 65: $341-346,1992$ 
145. Guo YS, Narayan S, Yallampalli C and Singh P: Characterization of insulinlike growth factor I receptors in human colon cancer. Gastroenterology 102: 1101-1108, 1992.

146. Freier S, Weiss O, Eran M, Flyvbjerg A, Dahan R, Nephesh I, Safra T, Shiloni E and Raz I: Expression of the insulin-like growth factors and their receptors in adenocarcinoma of the colon. Gut 44: 704-708, 1999.

147. Hakam A, Yeatman TJ, Lu L, Mora L, Marcet G, Nicosia SV, Karl RC and Coppola D: Expression of insulin-like growth factor-1 receptor in human colorectal cancer. Hum Pathol 30: $1128-1133,1999$.

148. Lee J, Jain A, Kim P, Lee T, Kuller A, Princen F, In-GuDo, Kim SH, Park JO, Park YS, et al: Activated cMET and IGF1R-driven PI3K signaling predicts poor survival in colorectal cancers independent of KRAS mutational status. PLoS One 9: e103551, 2014

149. Soubry A, Il'yasova D, Sedjo R, Wang F, Byers T, Rosen C, Yashin A, Ukraintseva S, Haffner S and D'Agostino R Jr: Increase in circulating levels of IGF-1 and IGF-1/IGFBP-3 molar ratio over a decade is associated with colorectal adenomatous polyps. Int J Cancer 131: 512-517, 2012.

150. Ollberding NJ, Cheng I, Wilkens LR, Henderson BE, Pollak MN, Kolonel LN and Le Marchand L: Genetic variants, prediagnostic circulating levels of insulin-like growth factors, insulin, and glucose and the risk of colorectal cancer: The Multiethnic Cohort study. Cancer Epidemiol Biomarkers Prev 21: 810-820, 2012.

151. Giovannucci E: Insulin, insulin-like growth factors and colon cancer: A review of the evidence. J Nutr 131 (Suppl): 3109S-3120S, 2001

152. Shiratsuchi I, Akagi Y, Kawahara A, Kinugasa T, Romeo K, Yoshida T, Ryu Y, Gotanda Y, Kage M and Shirouzu K: Expression of IGF-1 and IGF-1R and their relation to clinicopathological factors in colorectal cancer. Anticancer Res 31: 2541-2545, 2011.

153. Peters G, Gongoll S, Langner C, Mengel M, Piso P, Klempnauer J, Rüschoff J, Kreipe H and von Wasielewski R: IGF-1R, IGF-1 and IGF-2 expression as potential prognostic and predictive markers in colorectal-cancer. Virchows Arch 443: 139-145, 2003.

154.Furlanetto RW, Harwell SE and Frick KK: Insulin-like growth factor-I induces cyclin-D1 expression in MG63 human osteosarcoma cells in vitro. Mol Endocrinol 8: 510-517, 1994.

155. Sahin AA, Ro JY, Brown RW, Ordonez NG, Cleary KR, el-Naggar AK, Wilson P and Ayala AG: Assessment of Ki-67-derived tumor proliferative activity in colorectal adenocarcinomas. Mod Pathol 7: 17-22, 1994.

156. Kubota Y, Petras RE, Easley KA, Bauer TW, Tubbs RR and Fazio VW: Ki-67-determined growth fraction versus standard staging and grading parameters in colorectal carcinoma. A multivariate analysis. Cancer 70: 2602-2609, 1992.

157. Cascinu S, Del Ferro E, Grianti C, Ligi M, Ghiselli R, Foglietti G, Saba V, Lungarotti F and Catalano G: Inhibition of tumor cell kinetics and serum insulin growth factor I levels by octreotide in colorectal cancer patients. Gastroenterology 113: 767-772, 1997.

158. Bowers LW, Rossi EL, O'Flanagan CH, deGraffenried LA and Hursting SD: The Role of the Insulin/IGF System in Cancer: Lessons Learned from Clinical Trials and the Energy Balance-Cancer Link. Front Endocrinol (Lausanne) 6: 77, 2015.

159.Firth SM and Baxter RC: Cellular actions of the insulin-like growth factor binding proteins. Endocr Rev 23: 824-854, 2002.

160. Liou JM, Shun CT, Liang JT, Chiu HM, Chen MJ, Chen CC, Wang HP, Wu MS and Lin JT: Plasma insulin-like growth factor-binding protein-2 levels as diagnostic and prognostic biomarker of colorectal cancer. J Clin Endocrinol Metab 95: 1717-1725, 2010.

161.Jones JI and Clemmons DR: Insulin-like growth factors and their binding proteins: Biological actions. Endocr Rev 16: 3-34, 1995.

162. Héron-Milhavet L and LeRoith D: Insulin-like growth factor I induces MDM2-dependent degradation of p53 via the p38 MAPK pathway in response to DNA damage. J Biol Chem 277: 15600-15606, 2002.

163.Peretz S, Jensen R, Baserga R and Glazer PM: ATM-dependent expression of the insulin-like growth factor-I receptor in a pathway regulating radiation response. Proc Natl Acad Sci USA 98: 1676-1681, 2001.

164. Huang F, Xu LA and Khambata-Ford S: Correlation between gene expression of IGF-1R pathway markers and cetuximab benefit in metastatic colorectal cancer. Clin Cancer Res 18: 1156-1166, 2012
165. Jones HE, Goddard L, Gee JM, Hiscox S, Rubini M, Barrow D, Knowlden JM, Williams S, Wakeling AE and Nicholson RI: Insulin-like growth factor-I receptor signalling and acquired resistance to gefitinib (ZD1839; Iressa) in human breast and prostate cancer cells. Endocr Relat Cancer 11: 793-814, 2004.

166. Albanell $\mathrm{J}$ and Baselga $\mathrm{J}$ : Unraveling resistance to trastuzumab (Herceptin): Insulin-like growth factor-I receptor, a new suspect. J Natl Cancer Inst 93: 1830-1832, 2001.

167. Shen K, Cui D, Sun L, Lu Y, Han M and Liu J: Inhibition of IGF-IR increases chemosensitivity in human colorectal cancer cells through MRP-2 promoter suppression. J Cell Biochem 113: 2086-2097, 2012.

168. Warren RS, Yuan H, Matli MR, Ferrara N and Donner DB: Induction of vascular endothelial growth factor by insulin-like growth factor 1 in colorectal carcinoma. J Biol Chem 271: 29483-29488, 1996.

169. Akagi Y, Liu W, Zebrowski B, Xie K and Ellis LM: Regulation of vascular endothelial growth factor expression in human colon cancer by insulin-like growth factor-I. Cancer Res 58: 4008-4014, 1998

170.Sekharam M, Zhao H, Sun M, Fang Q, Zhang Q, Yuan Z, Dan HC, Boulware D, Cheng JQ and Coppola D: Insulin-like growth factor 1 receptor enhances invasion and induces resistance to apoptosis of colon cancer cells through the Akt/Bcl-x(L) pathway. Cancer Res 63: 7708-7716, 2003.

171.Zhang QY, Wang L, Song ZY and Qu XJ: Knockdown of type I insulin-like growth factor receptor inhibits human colorectal cancer cell growth and downstream PI3K/Akt, WNT/ $\beta$-catenin signal pathways. Biomed Pharmacother 73: 12-18, 2015.

172. Nahor I, Abramovitch S, Engeland $\mathrm{K}$ and Werner $\mathrm{H}$ : The p53-family members p63 and p73 inhibit insulin-like growth factor-I receptor gene expression in colon cancer cells. Growth Horm IGF Res 15: 388-396, 2005.

173. Ramocki NM, Wilkins HR, Magness ST, Simmons JG, Scull BP, Lee GH, McNaughton KK and Lund PK: Insulin receptor substrate-1 deficiency promotes apoptosis in the putative intestinal crypt stem cell region, limits Apcmin/+ tumors, and regulates Sox9. Endocrinology 149: 261-267, 2008.

174. Chan BT and Lee AV: Insulin receptor substrates (IRSs) and breast tumorigenesis. J Mammary Gland Biol Neoplasia 13: 415-422, 2008.

175. Esposito DL, Aru F, Lattanzio R, Morgano A, Abbondanza M, Malekzadeh R, Bishehsari F, Valanzano R, Russo A, Piantelli M, et al: The insulin receptor substrate 1 (IRS1) in intestinal epithelial differentiation and in colorectal cancer. PLoS One 7: e36190, 2012.

176. Day E, Poulogiannis G, McCaughan F, Mulholland S, Arends MJ, Ibrahim AE and Dear PH: IRS2 is a candidate driver oncogene on 13q34 in colorectal cancer. Int J Exp Pathol 94: 203-211, 2013

177. Slattery ML, Samowitz W, Curtin K, Ma KN, Hoffman M, Caan B and Neuhausen S: Associations among IRS1, IRS2, IGF1, and IGFBP3 genetic polymorphisms and colorectal cancer. Cancer Epidemiol Biomarkers Prev 13: 1206-1214, 2004.

178. Sanchez-Lopez E, Flashner-Abramson E, Shalapour S, Zhong Z, Taniguchi K, Levitzki A and Karin M: Targeting colorectal cancer via its microenvironment by inhibiting IGF-1 receptor-insulin receptor substrate and STAT3 signaling. Oncogene 35: 2634-2644, 2016.

179. Krajewski W, Dzięgała M, Kołodziej A, Dembowski J and Zdrojowy R: Vitamin D and urological cancers. Cent European J Urol 69: 139-147, 2016.

180. Lef kowitz ES and Garland CF: Sunlight, vitamin D, and ovarian cancer mortality rates in US women. Int J Epidemiol 23: 1133-1136, 1994.

181. Uitterlinden AG, Fang Y, Van Meurs JB, Pols HA and Van Leeuwen JP: Genetics and biology of vitamin D receptor polymorphisms. Gene 338: 143-156, 2004.

182. Boscoe FP and Schymura MJ: Solar ultraviolet-B exposure and cancer incidence and mortality in the United States, 1993-2002. BMC Cancer 6: 264, 2006.

183. Bishop JE, Collins ED, Okamura WH and Norman AW: Profile of ligand specificity of the vitamin D binding protein for 1 alpha,25-dihydroxyvitamin D3 and its analogs. J Bone Miner Res 9: 1277-1288, 1994.

184. Bikle D: Vitamin D: Production, Metabolism, and Mechanisms of Action. In: Endotext [Internet]. Feingold KR, Anawalt B, Boyce A, et al (eds). MDText.com, Inc., South Dartmouth, MA, 2000. 
185. Feskanich D, Ma J, Fuchs CS, Kirkner GJ, Hankinson SE, Hollis BW and Giovannucci EL: Plasma vitamin D metabolites and risk of colorectal cancer in women. Cancer Epidemiol Biomarkers Prev 13: 1502-1508, 2004.

186. Braun MM, Helzlsouer KJ, Hollis BW and Comstock GW: Colon cancer and serum vitamin D metabolite levels 10-17 years prior to diagnosis. Am J Epidemiol 142: 608-611, 1995.

187. Gorham ED, Garland CF, Garland FC, Grant WB, Mohr SB Lipkin M, Newmark HL, Giovannucci E, Wei M and Holick MF: Vitamin D and prevention of colorectal cancer. J Steroid Biochem Mol Biol 97: 179-194, 2005.

188. Garland C, Shekelle RB, Barrett-Connor E, Criqui MH, Rossof AH and Paul O: Dietary vitamin D and calcium and risk of colorectal cancer: A 19-year prospective study in men. Lancet 1: 307-309, 1985.

189. Garland CF and Garland FC: Do sunlight and vitamin D reduce the likelihood of colon cancer? Int J Epidemiol 9: 227-231, 1980.

190. Belleli A, Shany S, Levy J, Guberman R and Lamprecht SA: A protective role of 1,25-dihydroxyvitamin D3 in chemically induced rat colon carcinogenesis. Carcinogenesis 13: 2293-2298, 1992.

191. Comer PF, Clark TD and Glauert HP: Effect of dietary vitamin D3 (cholecalciferol) on colon carcinogenesis induced by 1,2-dimethylhydrazine in male Fischer 344 rats. Nutr Cancer 19 113-124, 1993.

192. Thomas MG, Tebbutt S and Williamson RC: Vitamin D and its metabolites inhibit cell proliferation in human rectal mucosa and a colon cancer cell line. Gut 33: 1660-1663, 1992.

193. Brehier A and Thomasset M: Human colon cell line HT-29: Characterisation of 1,25-dihydroxyvitamin D3 receptor and induction of differentiation by the hormone. J Steroid Biochem 29: 265-270, 1988.

194. Cross HS, Farsoudi KH and Peterlik M: Growth inhibition of human colon adenocarcinoma-derived Caco-2 cells by 1,25-dihydroxyvitamin D3 and two synthetic analogs: Relation to in vitro hypercalcemic potential. Naunyn Schmiedebergs Arch Pharmacol 347: 105-110, 1993.

195. Vandewalle B, Adenis A, Hornez L, Revillion F and Lefebvre J: 1,25-dihydroxyvitamin D3 receptors in normal and malignant human colorectal tissues. Cancer Lett 86: 67-73, 1994.

196.Zhao X and Feldman D: Regulation of vitamin D receptor abundance and responsiveness during differentiation of HT-29 human colon cancer cells. Endocrinology 132: 1808-1814, 1993.

197. Carlberg C and Dunlop TW: An integrated biological approach to nuclear receptor signaling in physiological control and disease. Crit Rev Eukaryot Gene Expr 16: 1-22, 2006.

198.Padi SK, Zhang Q, Rustum YM, Morrison C and Guo B: MicroRNA-627 mediates the epigenetic mechanisms of vitamin D to suppress proliferation of human colorectal cancer cells and growth of xenograft tumors in mice. Gastroenterology 145: 437-446, 2013.

199. Fernandez-Garcia NI,PalmerHG, Garcia M, Gonzalez-Martin A, del Rio M, Barettino D, Volpert O, Muñoz A and Jimenez B: 1alpha,25-Dihydroxyvitamin D3 regulates the expression of Id1 and Id 2 genes and the angiogenic phenotype of human colon carcinoma cells. Oncogene 24: 6533-6544, 2005.

200.Pendás-Franco N, Aguilera O, Pereira F, González-Sancho JM and Muñoz A: Vitamin D and Wnt/ $\beta$-catenin pathway in colon cancer: Role and regulation of DICKKOPF genes. Anticancer Res 28 (5A): 2613-2623, 2008

201. Ylikomi T, Laaksi I, Lou YR, Martikainen P, Miettinen S, Pennanen P, Purmonen S, Syvälä H, Vienonen A and Tuohimaa P: Antiproliferative action of vitamin D. Vitam Horm 64: 357-406, 2002

202. Taghizadeh F, Tang MJ and Tai IT: Synergism between vitamin D and secreted protein acidic and rich in cysteine-induced apoptosis and growth inhibition results in increased susceptibility of therapy-resistant colorectal cancer cells to chemotherapy. Mol Cancer Ther 6: 309-317, 2007.

203.Pálmer HG, Sánchez-Carbayo M, Ordóñez-Morán P,Larriba MJ, Cordón-Cardó C and Muñoz A: Genetic signatures of differentiation induced by 1alpha,25-dihydroxyvitamin D3 in human colon cancer cells. Cancer Res 63: 7799-7806, 2003.

204. Jensen SS, Madsen MW, Lukas J, Binderup L and Bartek J: Inhibitory effects of 1alpha,25-dihydroxyvitamin $\mathrm{D}(3)$ on the $\mathrm{G}(1)-\mathrm{S}$ phase-controlling machinery. Mol Endocrinol 15: 1370-1380, 2001.

205. Scaglione-Sewell BA, Bissonnette M, Skarosi S, Abraham C and Brasitus TA: A vitamin D3 analog induces a G1-phase arrest in CaCo-2 cells by inhibiting cdk2 and cdk6: Roles of cyclin E, p21Waf1, and p27Kip1. Endocrinology 141: 3931-3939, 2000.
206. Liu W, Chen Y, Golan MA, Annunziata ML, Du J, Dougherty U, Kong J, Musch M, Huang Y, Pekow J, et al: Intestinal epithelial vitamin $\mathrm{D}$ receptor signaling inhibits experimental colitis. J Clin Invest 123: 3983-3996, 2013

207. Murillo G, Nagpal V, Tiwari N, Benya RV and Mehta RG: Actions of vitamin D are mediated by the TLR4 pathway in inflammation-induced colon cancer. J Steroid Biochem Mol Biol 121: 403-407, 2010.

208. Kim KE and Brasitus TA: The role of vitamin D in normal and pathologic processes in the colon. Curr Opin Gastroenterol 17: 72-77, 2001.

209. Revelli A, Massobrio M and Tesarik J: Nongenomic effects of 1 1 ,25-dihydroxyvitamin D(3). Trends Endocrinol Metab 9: 419-427, 1998

210. Norman AW, Song X,Zanello L, Bula C and Okamura WH: Rapid and genomic biological responses are mediated by different shapes of the agonist steroid hormone, $1 \alpha, 25(\mathrm{OH}) 2$ vitamin D3. Steroids 64: 120-128, 1999.

211. Sitrin MD, Bissonnette M, Bolt MJ, Wali R, Khare S, Scaglione-Sewell B, Skarosi $\mathrm{S}$ and Brasitus TA: Rapid effects of $1,25(\mathrm{OH}) 2$ vitamin $\mathrm{D} 3$ on signal transduction systems in colonic cells. Steroids 64: 137-142, 1999.

212. Nelson WJ and Nusse R: Convergence of Wnt, beta-catenin, and cadherin pathways. Science 303: 1483-1487, 2004

213. Jeanes A, Gottardi CJ and Yap AS: Cadherins and cancer: How does cadherin dysfunction promote tumor progression? Oncogene 27: 6920-6929, 2008.

214. Rozen F, Yang XF, Huynh H and Pollak M: Antiproliferative action of vitamin D-related compounds and insulin-like growth factor-binding protein 5 accumulation. J Natl Cancer Inst 89: 652-656, 1997.

215. Kaler P, Augenlicht L and Klampfer L: Macrophage-derived IL-1beta stimulates Wnt signaling and growth of colon cancer cells: A crosstalk interrupted by vitamin D3. Oncogene 28: 3892-3902, 2009.

216. Kaler P, Galea V, Augenlicht L and Klampfer L: Tumor associated macrophages protect colon cancer cells from TRAIL-induced apoptosis through IL-1beta-dependent stabilization of Snail in tumor cells. PLoS One 5: e11700, 2010.

217. Chen A, Davis BH, Sitrin MD, Brasitus TA and Bissonnette M: Transforming growth factor-beta 1 signaling contributes to Caco-2 cell growth inhibition induced by $1,25(\mathrm{OH})(2) \mathrm{D}(3)$. Am J Physiol Gastrointest Liver Physiol 283: G864-G874, 2002.

218. Yanagisawa J, Yanagi Y, Masuhiro Y, Suzawa M, Watanabe M, Kashiwagi K, Toriyabe T, Kawabata M, Miyazono K and Kato S: Convergence of transforming growth factor-beta and vitamin D signaling pathways on SMAD transcriptional coactivators. Science 283: 1317-1321, 1999.

219. Deeb KK, Trump DL and Johnson CS: Vitamin D signalling pathways in cancer: Potential for anticancer therapeutics. Nat Rev Cancer 7: 684-700, 2007.

220. Tong WM, Hofer H, Ellinger A, Peterlik M and Cross HS: Mechanism of antimitogenic action of vitamin D in human colon carcinoma cells: Relevance for suppression of epidermal growth factor-stimulated cell growth. Oncol Res 11: 77-84, 1999.

221. Ben-Shoshan M, Amir S, Dang DT, Dang LH, Weisman Y and Mabjeesh NJ: 1alpha,25-dihydroxyvitamin D3 (Calcitriol) inhibits hypoxia-inducible factor-1/vascular endothelial growth factor pathway in human cancer cells. Mol Cancer Ther 6: 1433-1439, 2007.

222. Harris DM and Go VL: Vitamin D and colon carcinogenesis. J Nutr 134 (Suppl): 3463S-3471S, 2004

223. Lappe JM, Travers-Gustafson D, Davies KM, Recker RR and Heaney RP: Vitamin D and calcium supplementation reduces cancer risk: Results of a randomized trial. Am J Clin Nutr 85: 1586-1591, 2007.

224. Binder G, Wittekindt N and Ranke MB: Noonan Syndrome: Genetics and Responsiveness to Growth Hormone Therapy. Horm Res Paediatr 67: 45-49, 2007.

225.Campbell GS: Growth-hormone signal transduction. J Pediatr 131: S42-S44, 1997.

226. Savage MO, Blum WF, Ranke MB, Postel-Vinay MC, Cotterill AM, Hall K, Chatelain PG, Preece MA and Rosenfeld RG: Clinical features and endocrine status in patients with growth hormone insensitivity (Laron syndrome). J Clin Endocrinol Metab 77: 1465-1471, 1993.

227. Gunawardane K, Hansen TK, Muller N, Christiansen JS and Jorgensen JOL: Normal Physiology of Growth Hormone in Adults. In: Endotext [Internet]. Feingold KR, Anawalt B and Boyce A (eds). MDText.com, Inc., South Dartmouth, MA, 2000. 
228. Slater MD and Murphy CR: Co-expression of interleukin-6 and human growth hormone in apparently normal prostate biopsies that ultimately progress to prostate cancer using low $\mathrm{pH}$, high temperature antigen retrieval. J Mol Histol 37: 37-41, 2006.

229. Waters MJ and Conway-Campbell BL: The oncogenic potential of autocrine human growth hormone in breast cancer. Proc Natl Acad Sci USA 101: 14992-14993, 2004.

230. Brooks AJ and Waters MJ: The growth hormone receptor: Mechanism of activation and clinical implications. Nat Rev Endocrinol 6: 515-525, 2010.

231. Brown-Borg HM and Bartke A: GH and IGF1: Roles in energy metabolism of long-living GH mutant mice. J Gerontol A Biol Sci Med Sci 67: 652-660, 2012

232. Chesnokova V, Zonis S, Zhou C, Recouvreux MV, Ben-Shlomo A, Araki T, Barrett R, Workman M, Wawrowsky K, Ljubimov VA, et al: Growth hormone is permissive for neoplastic colon growth. Proc Natl Acad Sci USA 113: E3250-E3259, 2016.
233. Morin PJ, Sparks AB, Korinek V, Barker N, Clevers H, Vogelstein B and Kinzler KW: Activation of beta-catenin-Tcf signaling in colon cancer by mutations in beta-catenin or APC. Science 275: 1787-1790, 1997.

234. Clevers $H$ and Nusse R: Wnt/ $\beta$-catenin signaling and disease. Cell 149: 1192-1205, 2012.

235. Koliarakis I, Messaritakis I, Nikolouzakis TK, Hamilos G, Souglakos $\mathbf{J}$ and Tsiaoussis $\mathbf{J}$ : Oral Bacteria and Intestinal Dysbiosis in Colorectal Cancer. Int J Mol Sci 20: 4146, 2019.

(i) (9) This work is licensed under a Creative Commons Attribution-NonCommercial-NoDerivatives 4.0 International (CC BY-NC-ND 4.0) License. 